\title{
Geophysical well log-motifs, lithology, stratigraphical aspects and correlation of the Ordovician succession in the Swedish part of the Baltic Basin
}

\author{
Mikael Erlström ${ }^{1,2}\left(\mathbb{D} \cdot\right.$ Daniel Sopher $^{3}$
}

Received: 3 December 2018 / Accepted: 2 April 2019 / Published online: 15 April 2019

(c) The Author(s) 2019

\begin{abstract}
The geophysical characteristics of the carbonate-dominated Ordovician succession is described using wire-line logging data from exploration wells located within the Swedish part of the Baltic Basin, both offshore and from the island of Gotland. The petrophysical properties and log-motifs are compared and correlated with the lithology of cores from the Hamra-10, Skåls-1 and Grötlingbo-1 wells on southern Gotland. The 80-125-m-thick Ordovician succession is divided into five log stratigraphic units $\mathrm{O}_{\mathrm{a}}-\mathrm{O}_{\mathrm{e}}$, which are correlated throughout the study area. The proposed log stratigraphy and wire-line log characteristics are evaluated and compared with the established Ordovician stratigraphy from the adjacent areas of Öland, Östergötland and South Estonia. The newly established log stratigraphy is also linked to the existing seismic stratigraphic framework for the study area and exemplified with a selection of interpreted seismic type sections from Gotland and the south Baltic Sea. The presented characterization, division and correlation provide a basis for understanding the lateral and vertical variation of the petrophysical properties, which are essential in assessing the sealing capacity of the Ordovician succession, in conjunction with storage of $\mathrm{CO}_{2}$ in the underlying Cambrian sandstone reservoir.
\end{abstract}

Keywords Gotland $\cdot$ Core descriptions $\cdot$ Carbonates $\cdot \mathrm{OPAB}$ dataset $\cdot \mathrm{CO}_{2}$-seal $\cdot$ Seismostratigraphy

\section{Introduction}

Geophysical well logs have long been used for lithological characterization and sequence analysis. Traditionally, vertical well log patterns have provided a means to interpret the depositional energy and setting of siliciclastic depositional systems (e.g., Milton and Emery 1996; Harris et al. 1999). Perhaps the most commonly used log for this purpose is the natural gamma ray $\log$, the response of which, often relates to the amount of potassium-bearing clay minerals in the

Mikael Erlström

mikael.erlstrom@sgu.se

Daniel Sopher

daniel.sopher@sgu.se

1 Geological Survey of Sweden, Kiliansgatan 10, 22350 Lund, Sweden

2 Department of Geology, Lund University, Sölvegatan 12, 22362 Lund, Sweden

3 Geological Survey of Sweden, Villavägen 18, 75128 Uppsala, Sweden succession. Hence, gamma ray measurements can be indirectly related to changes in the depositional setting, such as sea level changes and changes in climate, which influence the amount of terrigenous material entering the basin. In a siliciclastic system, relatively high natural gamma values typically indicate lower depositional energy and decreasing grain size, i.e., increasing amount of clay minerals. Gradual or abrupt changes in the natural gamma ray curve can also be used as an indicator of sea-level fluctuations, flooding surfaces or unconformities. Furthermore, the use of well log-motifs is widely used to define and correlate subsurface sedimentary successions with the same geophysical characteristics and interpreted lithology. This is especially the case where there is no or limited information from outcrops or cores, and hence the subsurface geological characterization must rely largely on well logging data.

However, the use of log-motifs for the identification of shifts in the depositional setting for carbonate-dominated successions is much less straightforward. This is mostly because the carbonate system differs from the siliciclastic one in that the changes in carbonate productivity must be taken into consideration. Furthermore, in a siliciclastic 
system, high sediment supply occurs during lowstands while in a carbonate system high productivity of carbonate generally occurs during highstands. The ratio between carbonate and siliciclastic material in carbonate systems (as well as siliciclastic systems) can be influenced by tectonics, paleoclimate and siliciclastic sediment supply. However, in carbonate systems, it is also related to the water temperature governing biogenic carbonate production (Flügel 2004). Processes such as diagenetic dissolution and condensed deposition, where clay minerals can be enriched, must also be considered in the interpretation. In condensed sequences, there might also be enrichment of authigenic glauconite that significantly increases the gamma ray reading. Despite these complex relationships, well logs from carbonate-dominated successions can prove important for correlation in combination with core references. Hood et al. (2003) exemplifies the use of gamma ray motifs in a mixed siliciclastic carbonate to carbonate succession for the identification of changes in sea level. However, a requirement for this approach to be valid is that the depositional setting must be relatively quiescent and the siliciclastic sediments entering the basin must be dominated by clay minerals. The Ordovician succession in the epicontinental Baltic Basin to a large extent meets these requirements, whereby it is characterized by starved sedimentation in a quiescent shallow shelf setting. Hence, shifts in sea level and climate can be considered to reflect the relationship between the amounts of carbonate and siliciclastic material in these deposits. Where a sea level rise will likely result in the deposition of a higher proportion of clay material, which will correspond to relatively high gamma ray values.

The interest regarding the Lower Palaeozoic succession in the Swedish sector of the Baltic Sea (Fig. 1) has recently increased with respect to its potential of hosting deep saline aquifers suitable for $\mathrm{CO}_{2}$ storage (Mortensen et al. 2016). According to the assessment by Anthonsen et al. (2014), potential for $\mathrm{CO}_{2}$ storage exists due to the occurrence of Cambrian sandstone aquifers with sufficient thickness, depth, porosity and permeability. Furthermore, these aquifers are overlain by a sequence of potentially suitable sealing beds. Evaluation of the storage capacity and characteristics of the Cambrian sandstone aquifers indicate that the effective storage capacity might range up to several gigatons of $\mathrm{CO}_{2}$, even though more realistic judgments indicate capacities less than one gigaton $\mathrm{CO}_{2}$ (Sopher et al. 2014; Mortensen et al. 2016). So far, much focus has been put on characterizing and (a)

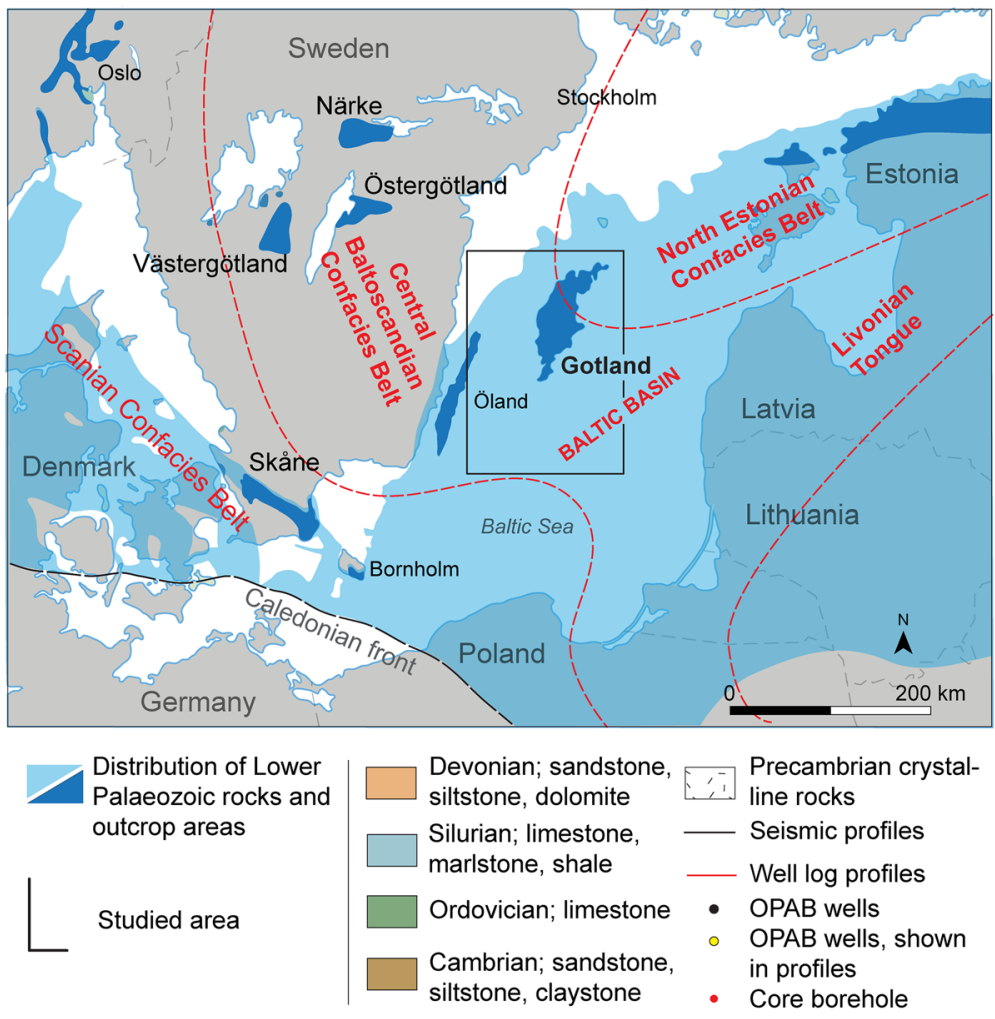

(b)

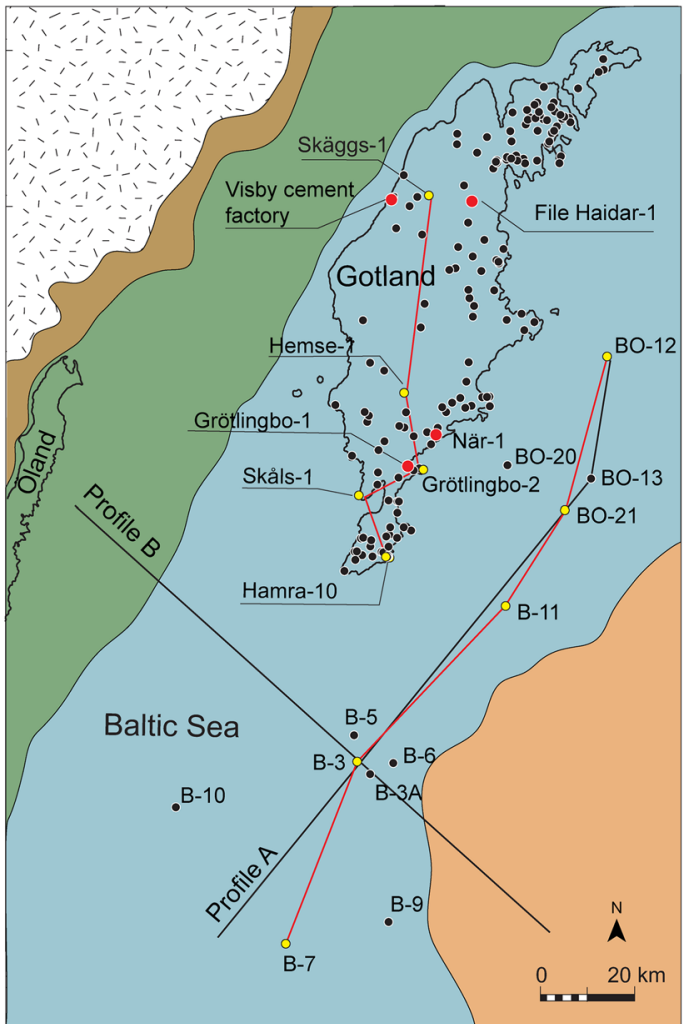

Fig. 1 a Map centered on the south Baltic Sea showing the distribution of Lower Palaeozoic rocks together with outcrop areas and confacies belts of Jaanusson (1976). b Schematic bedrock map of the study area showing well locations and cross sections discussed in the text 
describing the properties of the main Cambrian sandstone aquifers, of which the upper Miaolingian (former Series 3) Faludden sandstone is regarded the most prospective storage unit. Furongian strata are largely missing. Hence, the overlying Ordovician carbonate-dominated and Silurian marlstonedominated succession constitute, on Gotland and for much of the Swedish sector of the south Baltic Sea, the primary seal. However, unlike the reservoir, the petrophysical and lithological properties of the seal have not been extensively investigated.

In the Swedish part of the Baltic Basin, the knowledge about the Ordovician-Silurian succession is largely based on exploration data from wells and seismic surveys performed during the 1970s and 80s by the Swedish Oil and Gas prospecting company (OPAB). However, extensive geoscientific studies have been performed on the Ordovician succession in outcrop areas on the Swedish mainland and on the island of Öland (e.g., Stouge 2004; Calner et al. 2013; Lindskog 2017 and references therein). There are also numerous publications describing the Ordovician deposits in the Baltic countries, especially in Estonia where the Ordovician is widely exposed in an outcrop belt along and parallel to the depositional strike and distribution limit of the Palaeozoic succession (c.f. Harris et al. 2007; Nestor et al. 2007). In southern Estonia, Shogenov (2008) outlines a study of the subsurface Ordovician succession, which demonstrates the applicability of log-motifs for correlation and identifying bed units when cores are missing.

Despite these detailed studies and extensive exploration campaigns, merely a general characterization of the Ordovician succession beneath Gotland and the south-central parts of the Baltic Sea (Fig. 1) has so far been performed. Most of the geoscientific work has also been on the Upper Ordovician succession, which contains scattered oil-bearing carbonate mud mounds (Tuuling and Flodén 2000; Sivhed et al. 2004; Bergström et al. 2004; Kröger et al. 2017). The present stratigraphy of the Ordovician succession beneath Gotland and the Swedish sector of the Baltic Sea is largely based on an informal classification by OPAB (1976). Here, the succession is divided into three units. A lower 30-60-m-thick Bentonitic limestone followed by an up to ca 10 -m-thick Kvarne limestone and an upper 20-75-m-thick Klasen limestone unit. The latter holding most of the Upper Ordovician oil-bearing mounds. These informal stratigraphic units, however, are poorly defined and described, which highlights a need to re-evaluate their division with respect to the defined stratigraphy in neighboring areas such as Östergötland, Öland and South Estonia. The need to perform this task became apparent whilst performing a regional characterization of the Palaeozoic sequence in the Swedish sector of the Baltic Basin using seismic and well data collected by OPAB (Sopher et al. 2016). Here it was noted that the geophysical log responses from wells on Gotland and in the south-central Baltic Sea displayed characteristic log patterns for the Ordovician succession. These log-motifs appeared to repeat in most wells on Gotland and in the offshore area south and east of Gotland. Based on these observations this study was performed, which has focused on evaluating the geophysical logging results and their correlation to the observed rock types in cored intervals. The aim has been to investigate if the log-motifs allow for a geophysical division linked to specific lithofacies, stratigraphic units and the evolution of the Ordovician depositional setting in the Baltic Basin. Although this study does not include any biostratigraphic analyses, the log signatures are assessed regarding their coupling to known stratigraphic units and their lithological characteristics presented for Öland, Östergötland and Estonia (Stouge 2004; Calner et al. 2010, 2014; Munnecke et al. 2010; Bergström et al. 2011; Dronov 2017). Finally, the aim has also been to discuss and evaluate the coupling of the log-motifs to the sealing properties of the Ordovician succession.

\section{Geological framework}

The study area is in the south-central Baltic Sea. The area includes the island of Gotland and the areas south and immediately east of the island (Fig. 1). The Lower Palaeozoic in this area dips gently to the south and southeast, towards the central parts of the Baltic Basin. Hence, successively younger strata form the bedrock surface towards the southeast of the study area. Two interpreted seismic cross sections show the general outline of the sedimentary succession in the offshore part of the study area (Fig. 2).

The structural configuration of the Palaeozoic strata in the western Baltic Basin reflects multiple changes in tectonic regime during the Phanerozoic, i.e., the pre- to synCaledonian, Herzynian, Permian to Jurassic rifting and Late Cretaceous-Palaeogene inversion regimes. The west and northwest limit of the Lower Palaeozoic bedrock in the Baltic Sea is formed by extensive erosion due to uplift of the South Swedish Dome. This resulted in the removal of much of the previously extensive Lower Palaeozoic strata on the southern parts of the Baltic Shield (Japsen et al. 2015). Besides the coherent distribution in the Baltic Sea area, a few isolated outliers of Lower Palaeozoic strata are found in fault blocks, where they have been protected from erosion, for example, in Östergötland or beneath dolerite-capped table mountains in Västergötland (Calner et al. 2013). The northern and western extension limit of the Ordovician in the Baltic Sea is commonly marked by a submarine cliff composed of the relatively erosion-resistant limestonedominated Ordovician succession (Flodén 1980; Tuuling and Flodén 2016). The cliff is also clearly developed on the island of Öland where Lower and Middle Ordovician strata outcrop extensively. 

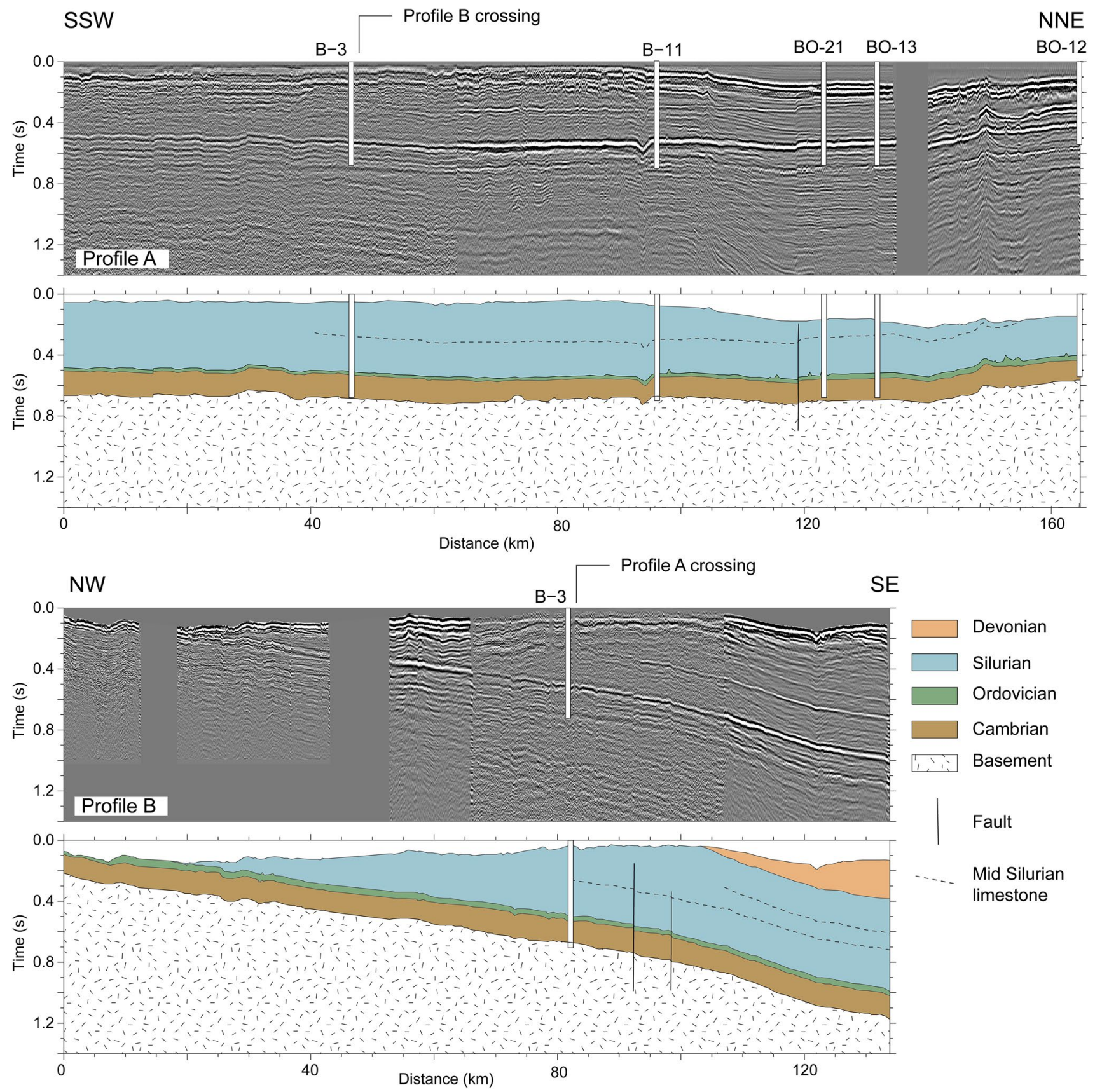

Fig. 2 Illustration exemplifying the general basin configuration and subsurface geology in two interpreted marine profiles A and B crossing the offshore area south of Gotland. The composite seismic data used to generate these profiles come from the OPAB dataset

Baltica was characterized by quiescent passive margin depositional settings during most of the Early Palaeozoic. The Cambrian sequence on top of the Precambrian basement includes an up to 250-m-thick succession of sandstone, siltstone and claystone, which represents progressive deposition coupled to the overall transgressive nature of the Cambrian sea. Stacked sequences of transgressive-regressive cycles with fining-upwards deposits grading from sand to clay are characteristic of the shore-face and inner shelf-dominated setting. The Cambrian sediments were laid down on a flat Precambrian shelf, i.e., the sub-Cambrian peneplain (Lidmar-Bergström and Olvmo 2015, and references therein). At this time, only a few isolated hills, a few tens of meters high, rose above the otherwise flat peneplain, for example, the Mossberga Dome on Öland (Stephansson 1971; Dahlqvist et al. 2018). These hills had, at least during the Early Cambrian, a role as submarine highs or islands on which no or very 
little sedimentation took place. It was not until later in the Cambrian that these were submerged and levelled out. Sivhed et al. (2004) proposed that these highs continued to influence the local marine setting during the Ordovician, where they resulted in areas preferential to the formation of mounds.

In the Early Ordovician, the independent plate Baltica was situated between approximately $40^{\circ}$ and $50^{\circ} \mathrm{S}$ and drifted towards lower latitudes resulting in gradually warmer marine conditions in the Late Ordovician (Cocks and Torsvik 2005, 2006). This is reflected in an overall change from sub-polar-cool water to tropical carbonate lithofacies (Jaanusson 1973; Harris et al. 2007). During the Ordovician, the Iapetus Ocean and Tornquist Sea surrounded the plate to the east and to the south. Hence, during the Ordovician, the Baltic Basin was subject to the effects of the Caledonian Orogeny: specifically, the progressive closure of the Tornquist Sea as the Avalonia microcontinent approached from the south and the approach of Laurentia from the west. The main phase of the Caledonian Orogeny was reflected by the high rates of deposition during the Late Silurian in a foreland basin setting, which evolved along the western margin of Baltica. Rates of deposition changed from 1 to $10 \mathrm{~m} / \mathrm{Ma}$ in the Lower Ordovician to more than $500 \mathrm{~m} / \mathrm{Ma}$ in the Late Silurian (Calner et al. 2013; Sopher et al. 2016).

Beneath Gotland, the top of the Ordovician is found between 150 and $250 \mathrm{~m}$ depth in the north and around $500 \mathrm{~m}$ in the southernmost parts. In the distal offshore part of the Swedish sector near the B-9 well, the top lies at ca $950 \mathrm{~m}$. Within the study area, the gross thickness of the Ordovician ranges between 80 and 125 meters, where the lower thicknesses are in the south. The greater thicknesses are associated with the local occurrences of Upper Ordovician mounds, primarily in the northeast parts of the area. The Ordovician succession is followed by a significantly thicker Silurian unit, which also constitutes the bedrock surface over much of the studied area (Fig. 1). In the southeastern part of the Swedish sector of the Baltic Sea, the up to ca 850-m-thick Silurian succession (which is capped by Pridoli reef barrier carbonates) is truncated by Lower Devonian reddish, terrigenous sandstones and siltstones, resulting in a discontinuity at the top of the Silurian (Fig. 2, Bjerkéus 2001).

The Ordovician sedimentation on Baltica took place in a shallow epeiric sea surrounded by low relief and tectonically stable landmasses supplying limited amounts of terrigenous sediments into the depositional areas. The deposition was characterized by generally low sedimentation rates as well as non-deposition, often resulting in a condensed carbonate succession. The sediments are, thus, dominated by argillaceous carbonates with variable amounts of skeletal carbonate fragments and grains. Variegated red-brown-grey wackestones and calcareous mudstones are the most common rock types. Increasing amounts of clay minerals in the deposits is interpreted to reflect more humid and warmer periods resulting in relatively high amounts of terrigenous clay entering the basin. The most common authigenic mineral is glauconite followed by pyrite.

The Ordovician depositional setting is commonly related to confacies belts which reflect the dominant lithofacies and bathymetric position of the depositional settings on Baltica (Jaanusson 1976). These belts transition from shallow waterdominated settings in the North Estonian Confacies Belt to inner shelf settings in the Central Baltoscandian Confacies Belt, which covers most of Scandinavia and the south Baltic Sea area (Fig. 1). Deeper marine conditions prevailed in the southwest corresponding to the Scanian Confacies Belt. Relatively deeper settings extended also from the southwest into a bay-like depression in the crust forming the Baltic Basin.

The study area is positioned between the North Estonian and the Central Baltoscandian Confacies belts (Fig. 1). Hence, within the study area, there is a transition from slightly deeper inner shelf settings in the south to shallower shelf and shore-face settings in the north. Furthermore, it may be assumed that the deposits more readily reflect sea-level fluctuations in the north, than in the south. Dronov et al. (2011) recognized for instance 14 third-order cycles in the Estonian Ordovician succession, which in relation to the succession beneath Gotland and the south-central Baltic Sea represents a shallower part of the Baltic Basin. Even if these minor cycles are difficult to identify in the deeper settings, several pronounced sea-level changes that influenced the whole depositional setting in the Baltoscandian Ordovician Sea are recognized. The most pronounced sea-level drop occurred in the upper Tremadocian, observed in the Bjørkåsholmen Formation (Fig. 3) which in Östergötland is characterized by a condensed sequence of glauconitic carbonates unconformably overlying Tremadocian fine-grained deeper water black shales belonging to the Alum Shale Formation (Egenhoff et al. 2010). On Öland glauconitic mixed clastics of the $<1.5$-m-thick Djupvik Formation are referred to as an eastern equivalent of the Bjørkåsholmen Formation (Stouge 2004; Egenhoff et al. 2010). On Öland, the basal-most part of the Hunneberg Stage is represented by a less than two-meter-thick condensed sequence of glauconitic limestone with thin interbeds of glauconitic shale and siltstone, i.e., the Köpingsklint Formation (Stouge 2004). In South Estonia, the Zebre Formation displays similar thickness and characteristics (Dronov 2017). These slowly deposited sediments were successively replaced by a series of cool-water carbonates reflecting a continuous sea level rise on the margin of Baltica (Fig. 3). Although the sea reached its maximum in the Floian the sea level remained relatively static until the Sandbian, which resulted in the formation of pure limestones in the Central Baltoscandian 


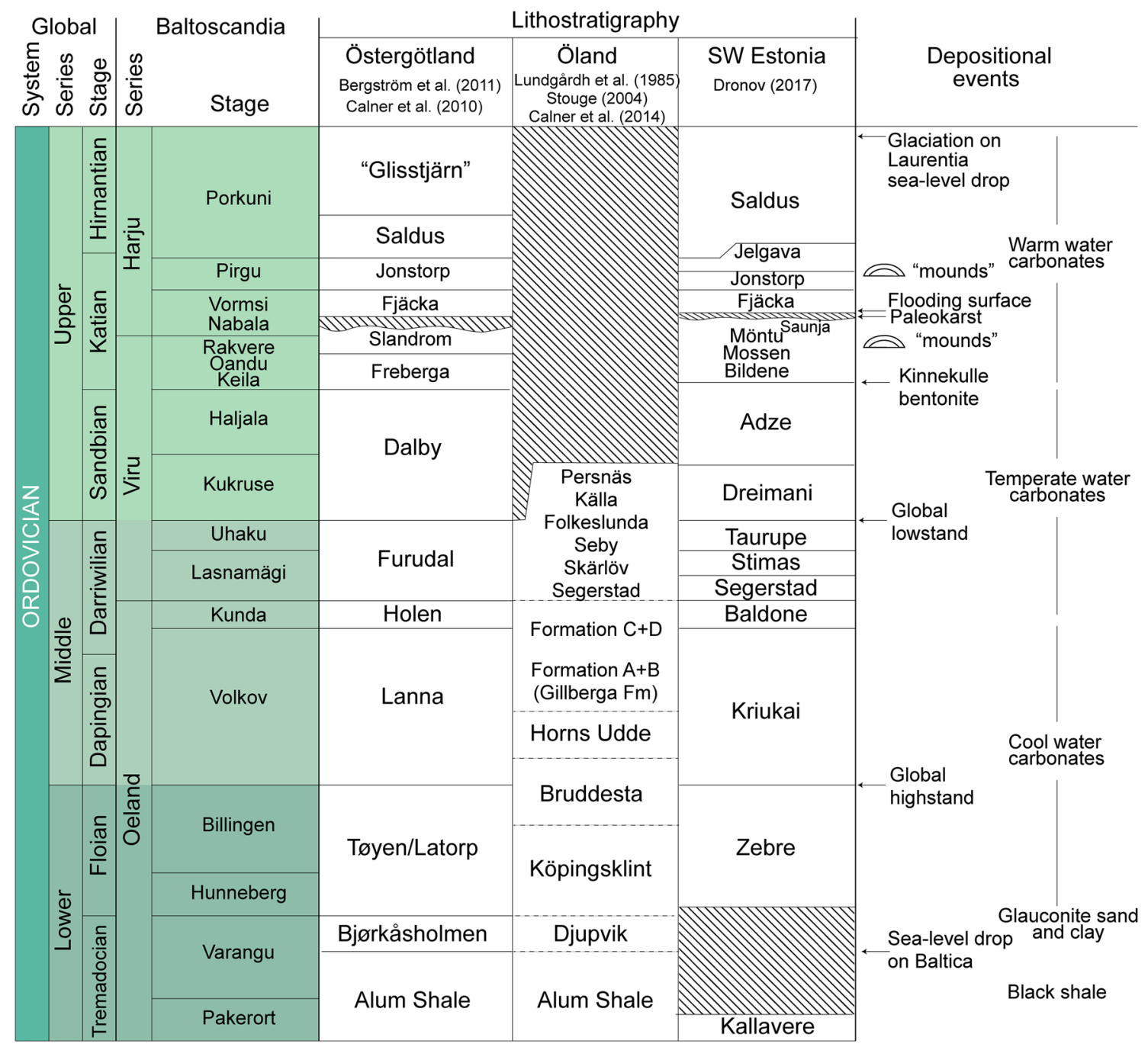

Fig. 3 Scheme showing the global and Baltoscandian Ordovician stratigraphy and lithostratigraphy in Östergötland, on Öland, in SW Estonia, and significant depositional events. The scheme is based on information from Bergström et al. (2009), Bergström et al. (2011), Calner et al. (2010, 2014), Stouge (2004), and Dronov (2017)

exposure and erosion of the bedrock during the middle Katian (Calner et al. 2010), prior to the deposition of the widespread Fjäcka Shale marking the return of deeper marine conditions to the margin of Baltica (Fig. 3). The Fjäcka Shale consists of variably organic-rich black shale and dark brown mudstone representing a major transgressive sequence in Baltoscandia. The shale is furthermore considered the source rock for the oil found in the Katian Kullsberg and Boda limestones in the Siljan region, central Sweden (Vlierboom et al. 1986; Ahmed et al. 2014). During the Late Ordovician, there was widespread development of biohermal reef-like mounds. The mounds occur in the late Keila-Nabala and Pirgu stages (Fig. 3, Bergström et al. 2004; Kröger et al. 2017) primarily within a band extending from Gotland towards North Estonia. They are interpreted to reflect that Baltica had reached 
more tropical and warmer latitudes promoting framework building ecosystems (Kröger et al. 2017). The mounds are commonly up to a few hundred meters in diameter and the height ranges from a few meters to several tens of meters (Sivhed et al. 2004). The most conspicuous effect is that they yield a relatively thick Upper Ordovician succession where they occur.

During the Hirnantian, Laurentia experienced a glaciation which resulted in a global sea-level drop. The Ordovician-Silurian boundary shows evidence that large parts of Baltica were then exposed and that the pre-existing Ordovician deposits were subject to erosion. Scored incised valleys and a widespread unconformity is documented at the Ordovician-Silurian boundary (Thorslund 1968; Tuuling and Flodén 2000).

\section{Material and methods}

From the 1970s to the late 1980s, OPAB performed extensive seismic surveys and borehole investigations of the Palaeozoic succession on Gotland and in the offshore areas in the south Baltic Sea. The initial targets were the Cambrian sandstones, but focus shifted later to the Upper Ordovician oil-bearing mounds. Prior to the extensive OPAB hydrocarbon exploration the only subsurface information came from a few cored boreholes.

As part of the exploration activities by OPAB large amounts of seismic reflection data were acquired both offshore and on Gotland. The data within the OPAB dataset typically have a lower resolution than the data used by Tuuling and Flodén $(2000,2009)$ but has greater depth penetration. Hence, it provides new information about the deepest parts of the Palaeozoic sequence in the Swedish parts of the Baltic Basin. In recent years, digitization and reprocessing of these data have made them more accessible and provided clearer images for interpretation. Subsequently, they have been used to provide additional insight into the Palaeozoic geology of the Baltic Basin (Sopher and Juhlin 2013; Sopher et al. 2016). In conjunction with this study and work by Levendal (2019), this database has been extended to include all profiles on Gotland.

The first deep borehole on Gotland was drilled in 1919 at Visby cement factory, followed years later by the File Haidar-1 borehole in 1937, and Grötlingbo-1 and När-1 in 1968 (see locations in Fig. 1). Geoscientific studies on these older cores constitute important references to the present study (e.g., Hedström 1923; Thorslund and Westergård 1938; Kjellström 1971; Männik et al. 2015).

Between 1972 and 1987, OPAB drilled 242 wells on Gotland and 12 wells in the Swedish offshore sector of the south Baltic Sea. Gotlandsolja AB, who took over the prospecting after OPAB, drilled an additional 80 wells between 1987 and 1992 on Gotland.

There is often comprehensive geophysical logging data from the first OPAB wells drilled on Gotland and in the offshore area. Besides the 12 offshore wells, 36 of the OPAB wells on Gotland contain wire-line logging data on the Ordovician succession, primarily from wells located on the south part of the island. The OPAB logging program was executed by Schlumberger and typically included a natural gamma ray log (GR), various electrical $\log$ s such as spontaneous potential (SP), induction (IND), dual lateral log resistivity (DLL) or micro-lateral resistivity (MLL). The logging program most often also included a borehole compensated sonic $\log$ (BHC) or formation density compensated log (FDC). A compensated neutron $\log (\mathrm{CNL})$ was only performed in few of the wells. All logged wells were studied but focus was put on the wells with the best log quality and similar logging suites (Table 1). Ten wells on Gotland and in the offshore area were selected for correlation of the Ordovician succession along two south-north-oriented sections.

Primarily, the GR log-motifs were used to illustrate the log-stratigraphic correlation between wells. The GR log is also the most useful $\log$ in evaluating the relationship between siliciclastic sediments and carbonate production in the depositional setting, which can be used as an indicator of sea-level changes. The GR measures the naturally occurring gamma radiation in the rock emitted from potassium- 40 and the isotope series associated with the decay of uranium and thorium. The log is especially useful for distinguishing clay-rich and non-clay-rich formations because potassium is a common component in clay minerals. The GR logs are scaled in American Petroleum Institute units, which is a calibrated standard scale used to facilitate comparison of the results from different tools.

The log-motifs of the BHC and the FDC have been used to distinguish dense limestone from less dense argillaceous intervals and as a support to the interpretation of the seismic response. The CNL in combination with the FDC has been used to separate limestone from more argillaceous lithologies such as mudstone, shale and marlstone. Since the measured CNL reading depends on the amount of hydrogen present, an argillaceous rock, e.g., shale, will consequently give a relatively higher CNL-porosity value in comparison to the FDC log, which is unaffected by the hydrogen content. The separation of the CNL to the left of the FDC in the log track gives a clear indication of argillaceous rocks. In limestone intervals, both the FDC and CNL will have about the same value while in sandstone the CNL will give a slightly lower porosity than the FDC. This straightforward interpretation to identify and separate clay-mineral-rich shale and mudstone intervals from limestone and sandstone intervals has been matched with the GR and the lithology of cored 
Table 1 Compilation of total depth, depth to the top and base of the Ordovician succession, available logging data and performed coring in the Ordovician interval for the wells shown in the profiles

\begin{tabular}{|c|c|c|c|c|c|c|c|}
\hline \multirow[t]{2}{*}{ Wells } & \multirow{2}{*}{$\begin{array}{l}\text { Drill floor, } \\
\text { m sl. }\end{array}$} & \multirow[t]{2}{*}{ Total depth, m } & \multicolumn{2}{|c|}{ Ordovician } & \multirow[t]{2}{*}{ Thickness, $\mathrm{m}$} & \multirow[t]{2}{*}{ Logging suites } & \multirow{2}{*}{$\begin{array}{l}\text { Cored intervals in the } \\
\text { Ordovician }\end{array}$} \\
\hline & & & Top & Bottom & & & \\
\hline \multicolumn{8}{|c|}{ On shore Gotland } \\
\hline Hamra-10 & +12.1 & 590.5 & 497 & 577 & 80 & $\begin{array}{l}\text { DLL-SP, BHC-GR-CAL, } \\
\text { MLL }\end{array}$ & $499.9-536.5$ \\
\hline Skåls-1 & +4.7 & 666.8 & 361 & 452 & 87 & $\begin{array}{l}\text { IES-SP, FDC-CAL GR- } \\
\text { SNP-CAL, MLL }\end{array}$ & $435.0-452.0$ \\
\hline Grötlingbo-2 & +4.5 & 666.0 & 398 & 480 & 82 & $\begin{array}{l}\text { IES-SP, FDC-GR-CAL, } \\
\text { MLL }\end{array}$ & $404.0-422.0474 .0-480.0$ \\
\hline Hemse-1 & +29.1 & 635.0 & 359 & 451 & 92 & $\begin{array}{l}\text { IES, BHC-GR-CAL } \\
\text { FDC, MLL }\end{array}$ & $438.0-451.0$ \\
\hline Skäggs-1 & +56.8 & 474.2 & 223 & 321 & 98 & $\begin{array}{l}\text { IES, BHC-GR-CAL FDC, } \\
\text { SNP, MLL }\end{array}$ & $300-321$ \\
\hline \multicolumn{8}{|c|}{ Offshore South Baltic Sea } \\
\hline B-3 & +21.5 & 1028.0 & 684 & 762 & 88 & $\begin{array}{l}\text { CNL-FDC-GR-CAL, } \\
\text { DLL-SP, MLL }\end{array}$ & - \\
\hline B-7 & +28.2 & 1037.5 & 786 & 858 & 72 & $\begin{array}{l}\text { CNL-FDC-GR-CAL, } \\
\text { DLL-SP }\end{array}$ & $850.0-858.5$ \\
\hline BO-11 & +25.0 & 1039.7 & 715 & 799 & 84 & $\begin{array}{l}\text { CNL-FDC-GR-CAL, } \\
\text { DLL-SP }\end{array}$ & - \\
\hline BO-12 & +24.7 & 818.2 & 489 & 595 & 106 & $\begin{array}{l}\text { DLL-SP-GR, CNL-FDC- } \\
\text { CAL }\end{array}$ & $\begin{array}{l}489.0-502.74 \\
504.7-514.8\end{array}$ \\
\hline BO-13 & +25.0 & 957.5 & 622 & 714 & 92 & $\begin{array}{l}\text { DLL-SP-GR, CNL-FDC- } \\
\text { CAL }\end{array}$ & - \\
\hline BO-21 & +25.0 & 955.0 & 590 & 715 & 125 & $\begin{array}{l}\text { DLL-SP-GR, CNL-FDC- } \\
\text { CAL }\end{array}$ & $590.0-594.0$ \\
\hline
\end{tabular}

All depths are in meters below drill floor

IES induction electric survey, $S P$ spontaneous potential, $F D C$ formation density compensated, $G R$ natural gamma, $C N L$ compensated neutron $\log , C A L$ caliper, $D L L$ dual lateral $\log$ resistivity, $B H C$ borehole compensated sonic, $M L L$ micro lateral resistivity $\log$

intervals in the studied wells. More detailed information on the interpretation and fundamentals of well logs are found in Serra (1984), Schlumberger (1991) and Rider and Kennedy (2011).

Cores exist in 50 of the OPAB wells on Gotland. However, most of the coring was performed over a few meters, either in the uppermost or lowermost part of the Ordovician succession. Furthermore, most cored intervals are not associated with any wire-line logging data. This fact disqualified most of the cored intervals for a comparative analysis between lithology and the log responses. Cored intervals from the Hamra-10 and Skåls-1 wells, located on south Gotland, were selected as suitable references to investigate the relationship between the lithology and the wire-line log responses (Figs. 4 and 5). These wells contain relatively continuous coring of the lowermost and uppermost parts of the Ordovician succession and also have a suite of highquality geophysical logs (Table 1). In addition, the lithological descriptions of the Grötlingbo- 1 core and the wireline logs from the adjacent Grötlingbo-2 well were used as a complementary source of information to investigate the match between the log responses for the parts of the Ordovician succession which are not covered by the cores from the selected reference wells.

A lithological characterization of 18 up to $20-\mathrm{cm}-$ long core pieces, selected to match various log responses, was performed on the Hamra-10 and Skåls-1 cores. This was done at the core archive managed by the Geological Survey of Sweden. The sampled core pieces were sawed lengthwise and the cut surface was polished and scanned using a photo scanner with a resolution of $1200 \mathrm{dpi}$. The scanned images of the various carbonate rock types were subsequently studied regarding texture and classified according to Dunham's classification (Dunham 1962).

\section{Log-motifs, lithology and stratigraphical aspects}

The log-motif of the Ordovician succession is divided into five main intervals $\left(\mathrm{O}_{\mathrm{a}}-\mathrm{O}_{\mathrm{e}}\right)$ distinguished by their diagnostic geophysical signatures. A composite log for Skåls-1 exemplifies the typical log-motifs for GR, FDC, CNL, BHC and MLL over the studied succession (Fig. 4). The two lower 


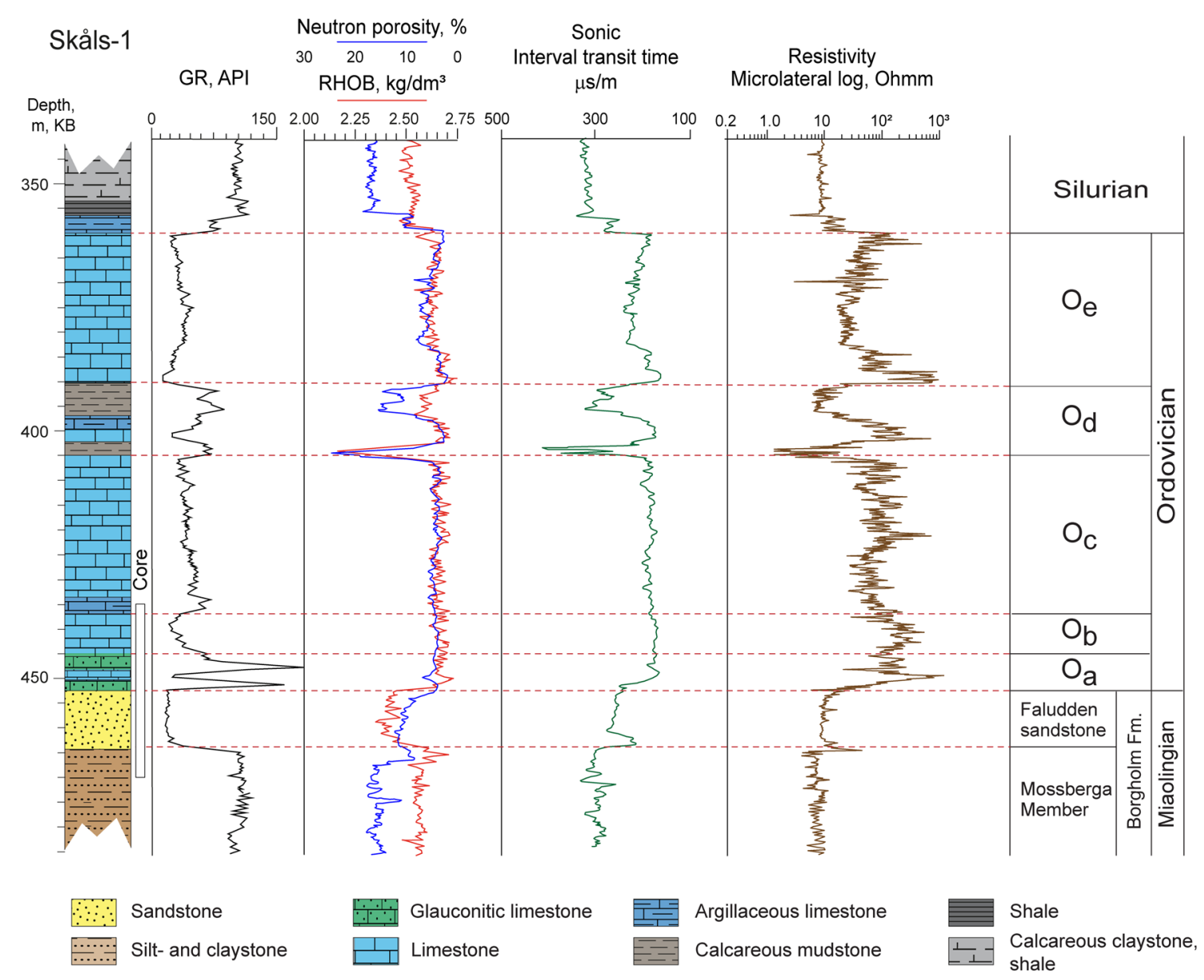

Fig. 4 Well log profiles of Skåls-1 exemplifying characteristic logmotifs for the gamma ray (GR), neutron, density (RHOB), sonic and resistivity logs for the Ordovician succession and the bounding Cam-

intervals $\mathrm{O}_{\mathrm{a}}-\mathrm{O}_{\mathrm{b}}$ and the lower meters of the $\mathrm{O}_{\mathrm{c}}$ interval are matched with rock types in cores from the Skåls- 1 well and the upper intervals $\left(\mathrm{O}_{\mathrm{d}}-\mathrm{O}_{\mathrm{e}}\right)$ with cores from the Hamra-10 well (Figs. 5, 6). Most of the $\mathrm{O}_{\mathrm{c}}$ interval is, however, only matched with core descriptions from the Grötlingbo- 1 core. The stratigraphic affinity is assessed with respect to work by OPAB (1976), Kjellström (1971), Bergström et al. (2004), Männik et al. (2015) on Gotland and by stratigraphical work on Öland (Stouge 2004) and in Östergötland (Bergström et al. 2011). In addition, inferences about the Upper Ordovician succession have been made based on the work by Calner et al. (2010). The log-motifs have also been compared with the overall evolution of the depositional setting during the Ordovician (Tuuling and Flodén 2000; Nielsen 2004; Kiipli et al. 2008; Munnecke et al. 2010; Dronov et al. 2011).

\section{The $\mathrm{O}_{\mathrm{a}}$ interval}

In most wells, the up to ca 10-m-thick lowermost $\mathrm{O}_{\mathrm{a}}$ interval overlies the Faludden Sandstone (Figs. 4 and 5). However, in brian and Silurian beds. The boundaries of the geophysical intervals $\mathrm{O}_{\mathrm{a}}-\mathrm{O}_{\mathrm{e}}$ are marked as well as the dominant lithology of the succession

a few wells on Gotland (e.g., Hemse-1) and in the offshore wells to the south (e.g., B-3, B-9 and B-7) it overlies a thin sequence of alum shale ( $<5 \mathrm{~m}$ thick), which overlies the Faludden Sandstone (Fig. 5). It is often difficult to precisely define the boundary between the glauconitic $\mathrm{O}_{\mathrm{a}}$ interval and the underlying alum shale since they show similar high GR-motifs. A coherent distribution and gradually increasing thickness of the alum shale is found towards the south and southeast of the B-3 well (Buchardt et al. 1997). The overall high GR values of the $\mathrm{O}_{\mathrm{a}}$ interval is matched by cores in Skåls-1 which display a dominance of extremely glauconitic carbonates. In many of the wells, the $\mathrm{O}_{\mathrm{a}}$ interval includes two high GR peaks, where the lower one coincides with glauconite grainstone and the upper peak is a glauconiterich packstone. Between these two significant GR peaks in Skåls-1 there are beds of brown and dark grey calcareous, bioturbated mudstone and wackestone without any visible glauconite (Fig. 6i). The upper glauconite-rich bed in Skåls-1 (Fig. 6h) cuts into the underlying mudstone forming an irregular unconformity. In the offshore wells to the south, 


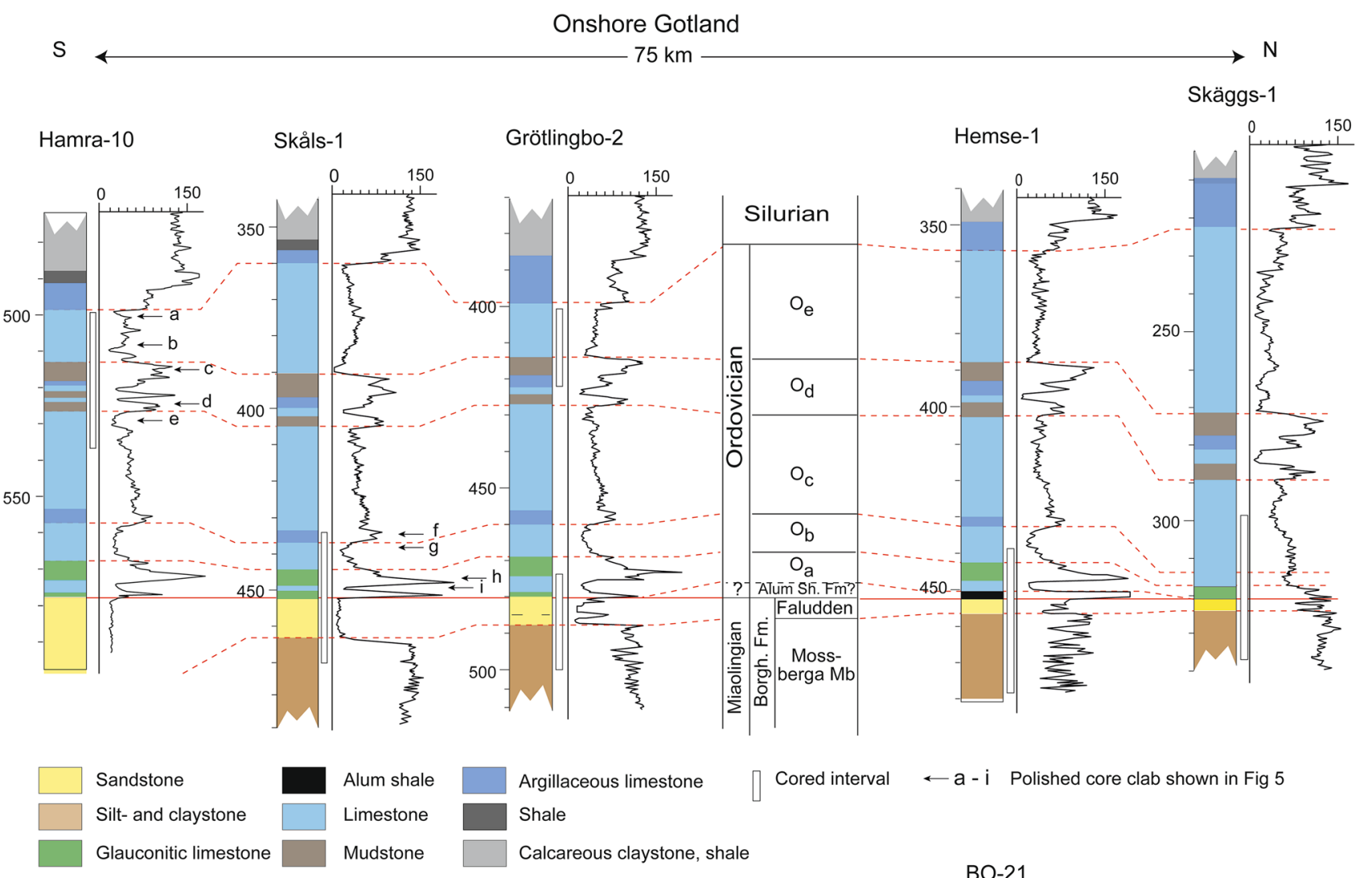

\section{BO-21}

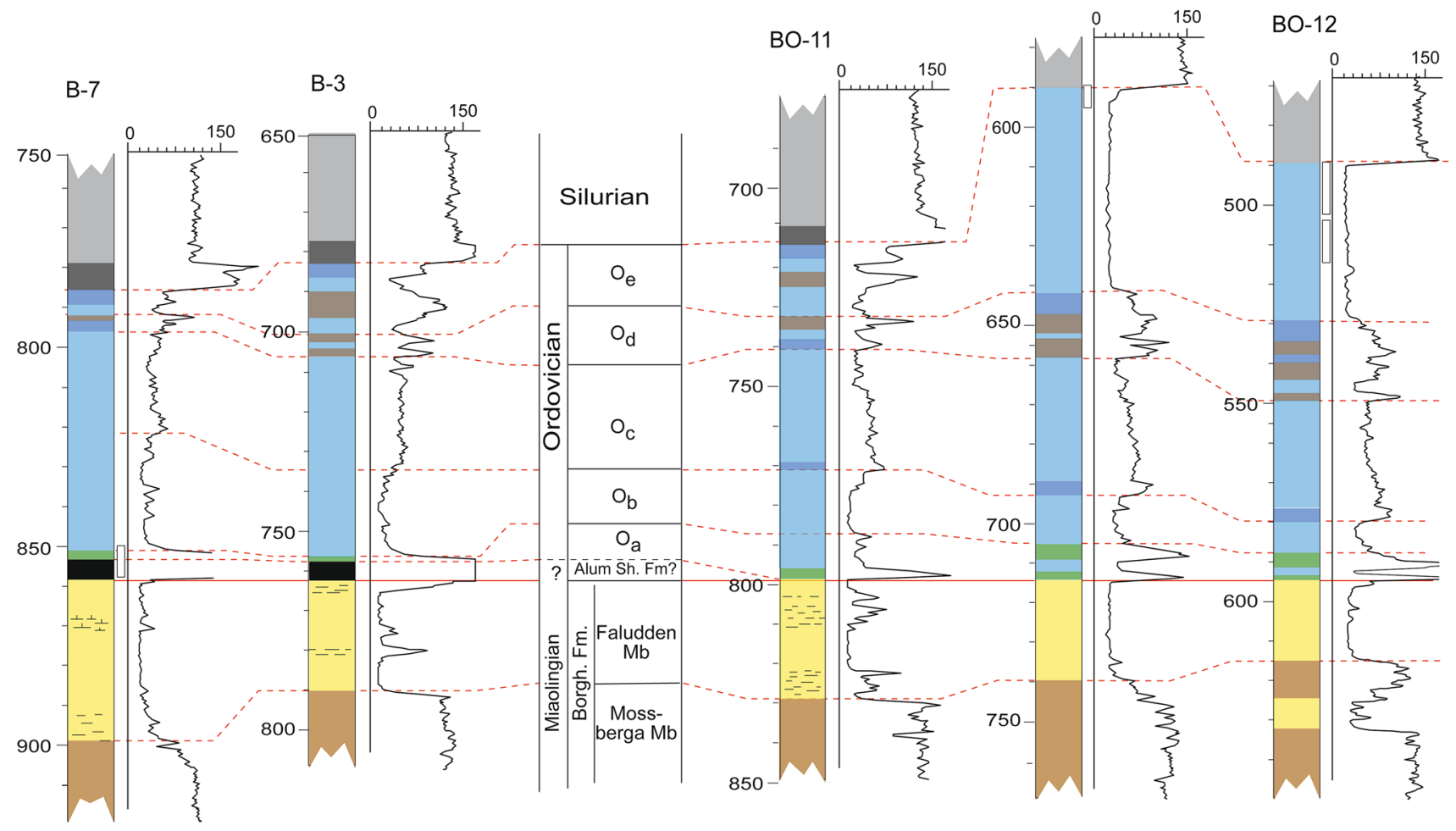

Offshore Gotland 
4Fig. 5 Well log profiles, GR log-motifs and correlation of the Ordovician and top Cambrian succession in selected wells along two sections on Gotland and in the south and east offshore area. Well locations are given in Fig. 1. The interpreted geophysical intervals $\mathrm{O}_{\mathrm{a}}-\mathrm{O}_{\mathrm{e}}$, are further described in the text and stratigraphically elaborated in Fig. 9

the $\mathrm{O}_{\mathrm{a}}$ interval is incorporated in a relatively broad high GR peak, which also includes beds of alum shale directly below the glauconite-rich $\mathrm{O}_{\mathrm{a}}$ interval. This is matched by the B-7 core between 850.0 and $862.0 \mathrm{~m}$. This core includes $4.9 \mathrm{~m}$ of alum shale overlying the Faludden sandstone, followed by $1.5 \mathrm{~m}$ of missing core and $1.0 \mathrm{~m}$ of glauconitic limestone and shale.

The upper part of the $\mathrm{O}_{\mathrm{a}}$ interval is characterized by gradually decreasing GR values indicating successively lower amounts of glauconite and a transition into more pure limestone facies (Figs. 5 and 6g).

On Öland, the basal part of the Ordovician carbonate succession is defined as the glauconite-rich Djupvik and Köpingsklint formations (Stouge 2004). These successions display very similar characteristics and thicknesses to the Lower Ordovician succession identified here in the well logs and reference core material from Gotland. Hence, the lower GR peak in the $\mathrm{O}_{\mathrm{a}}$ interval is interpreted to represent the Djupvik Formation and the corresponding Bjørkåsholmen Formation in Östergötland. The interval represented by the upper GR peak is interpreted to correspond to the glauconitic Köpingsklint Formation. These glauconitic bearing formations have been assigned to the upper Vorangi, Hunneberg and Billingen regional stages and represent a significant sea-level fall in the Baltic Basin (Fig. 3, Egenhoff et al. 2010). Similar glauconitic formations and layers of the Zebre Formation, representing the Hunneberg and Billingen stages, were also identified in well logs in South Estonian boreholes (Shogenov 2008).

\section{The $\mathrm{O}_{\mathrm{b}}$ and $\mathrm{O}_{\mathrm{c}}$ intervals}

The $\mathrm{O}_{\mathrm{b}}$ interval is characterized by much lower GR values in comparison to the previous interval, indicating less argillaceous and glauconitic carbonates. The BHC, FDC and the resistivity logs indicate tight and dense strata (cf. Fig. 4). The log-motif of the ca 10 -m-thick $\mathrm{O}_{\mathrm{b}}$ interval is very consistent in character on southern Gotland and easily correlated between wells (Fig. 5). On northern Gotland and in the BO-12 well the interval is only a few meters thick. The interval is significantly thicker (ca $25 \mathrm{~m}$ ) offshore to the south of Gotland (exemplified by the B-7 well, Fig. 5). Here it is characterized by less homogeneous GR motifs indicating alternating beds with varying ratios of carbonate and clay minerals (Fig. 5). In the Skåls-1 core, the interval is characterized by variegated grey and dark red wackestone, and grey packstone with numerous stylolites and iron-impregnated hardgrounds (Fig. $6 \mathrm{f}-\mathrm{g}$ ). This interval is bounded at the top by a thin bed, no more than a few meters thick, with significantly higher GR values that constitute the lower part of the $\mathrm{O}_{\mathrm{c}}$ interval.

The $\mathrm{O}_{\mathrm{c}}$ interval is, besides the basal meters, composed of relatively homogeneous beds of variegated red, brown and grey wackestones (Fig. 6e). The interval has a relatively consistent thickness of 30-35 m. In Skåls-1, the basal part of the $\mathrm{O}_{\mathrm{c}}$ interval is represented by grey wackestone with a slightly higher amount of siliciclastic material and is interpreted to correspond to the so-called "Täljsten", representing a period of regional sea-level drop at the end of the Volkov regional stage (Lindskog 2017).

The upper boundary of the $\mathrm{O}_{c}$ interval is defined by a high GR peak coinciding with the Kinnekulle Bentonite, verified by logging data and cores from the Grötlingbo- 1 well (Kjellström 1971; Männik et al. 2015).

It is possible to compare the $\mathrm{O}_{\mathrm{b}}-\mathrm{O}_{\mathrm{c}}$ intervals, i.e., the succession between the top of the Köpingsklint Formation and the base of the Kinnekulle Bentonite, with chemostratigraphic data from the Aizpute-41 core in western Latvia (Kiipli et al. 2008). On comparison, it is noted that the observed GR-motif (i.e., an overall decrease towards the top of the interval) in the Gotland wells is consistent with a successive decrease in the amount of terrigenous material observed in the Volkov-Haljala succession in Latvia. The dominance of cool water carbonates with a slow accumulation rate coupled with a low influx of terrigenous material is implied for the mid-Billingen to Volkov stages (cf. Harris et al. 2007). This fits with the ca 10-m-thick interval $(459.5-469.0 \mathrm{~m})$ at the base of the $\mathrm{O}_{\mathrm{b}}-\mathrm{O}_{\mathrm{c}}$ interval in the Grötlingbo-1 well which is composed of limestone facies with relatively low natural gamma levels (Fig. 5). On Öland, this interval corresponds to the Bruddesta Formation, Horns Udde Formation and Formations A and B (Stouge 2004). This transition is interpreted to reflect a general drop during the early Kunda stage, corresponding to the "Täljsten" interval of the Holen Limestone (see Dronov and Rozhnov 2007; Dronov et al. 2011; Lindskog 2017) and the synonymous Formation C and D on Öland (Stouge 2004).

On Öland, the interval between the "Täljsten" and the Kinnekulle Bentonite is divided into several stratigraphic units (see Stouge 2004). Traditionally, the interval has been referred to as the "orthoceratite limestones" of consistent composition, where dense variably reddish grey packstones dominate (Fig. 6e-g). In most wells, the GR motif shows a gradually decreasing value which is related to successively cleaner limestone facies over the $\mathrm{O}_{c}$ interval. However, besides this gradual lowering of the GR values, there are no other significant changes in the GR 

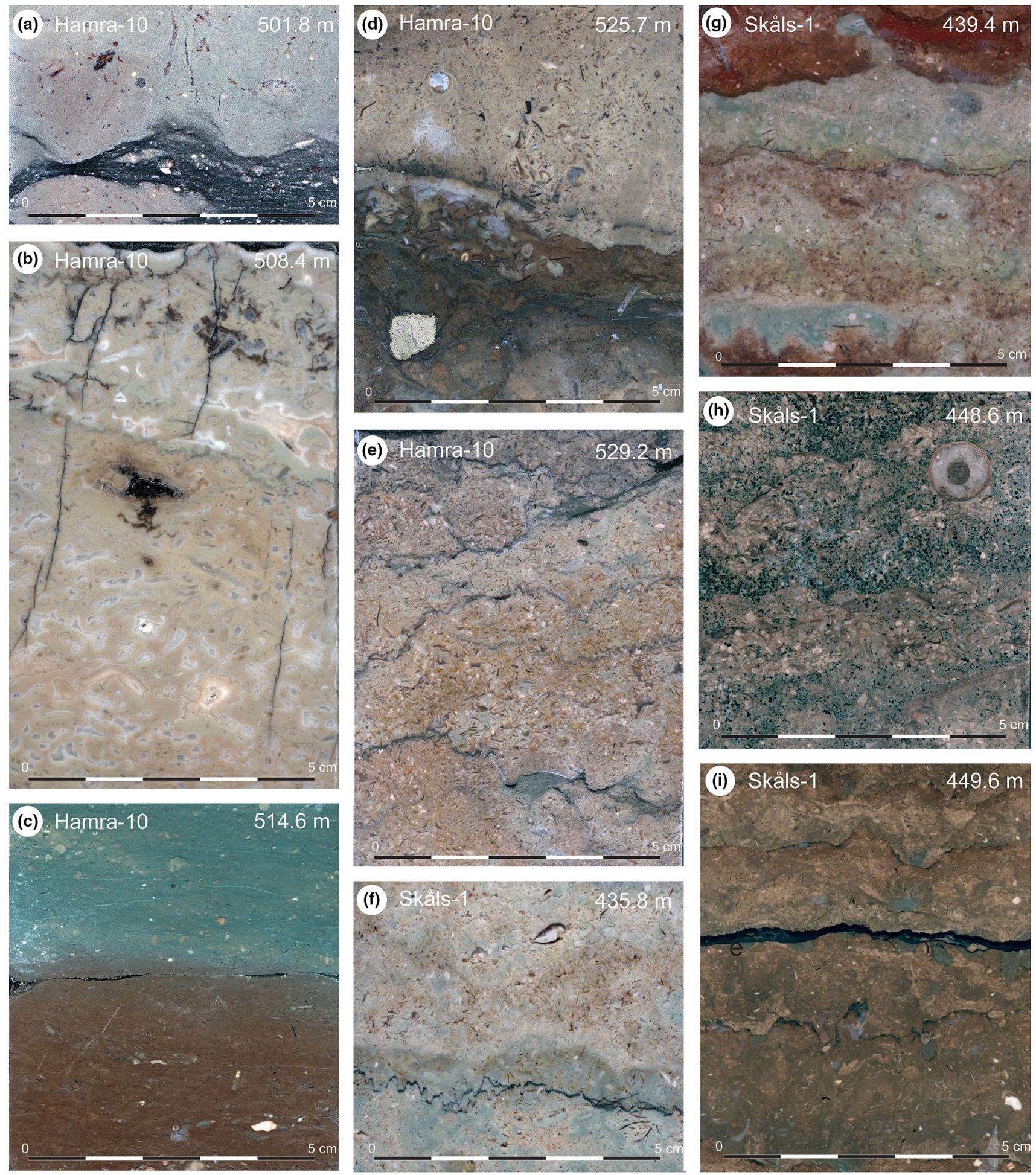

and $\mathrm{BHC}$ log-motifs which motivate a detailed division of the $\mathrm{O}_{\mathrm{c}}$ interval. This is also the case when considering the equivalent sequence on Öland, Östergötland or in west Estonia. Therefore, we have arbitrarily correlated this part to represent the Lasnamägi-Uhaku formations on Öland, i.e., Segerstad to Persnäs limestone formations (Lundegårdh et al. 1985), without defining their respective boundaries. Nevertheless, Kjellström (1971) and Männik et al. (2015) agree that in the Grötlingbo-1 core, the upper part of the $\mathrm{O}_{\mathrm{c}}$ interval corresponds to the Dalby Limestone. 
4Fig. 6 Photographs of polished core slabs from Skåls-1 and Hamra10 exemplifying some characteristic lithologies for the interpreted geophysical intervals $\mathrm{O}_{\mathrm{a}}-\mathrm{O}_{\mathrm{e}}$. All depths are in meters below the drill floor. a supra mound calcareous mudstone/wackestones with undulating clay laminae $\left(\mathrm{O}_{\mathrm{e}}\right.$ interval $)$, b intra-mound fenestral microbial bindstone with numerous oil-saturated vugs and microfractures $\left(\mathrm{O}_{e}\right.$ interval), $\mathbf{c}$ brown and green laminated mudstone of the Fjäcka Shale $\left(\mathrm{O}_{\mathrm{d}}\right.$ interval $)$, d mottled brown-dark-grey nodular mudstone topped by a marked glauconitic disrupted layer (discontinuity surface) with brown mud clasts, shell fragments and pyrite mineralization, followed by a contrasting beige to light brown packstone layer $\left(\mathrm{O}_{d}\right.$ interval), e grey and light red packstone and wackestone (upper $\mathrm{O}_{c}$ interval), f light grey and light brown packstone-wackestone with stylolites (lower $\mathrm{O}_{\mathrm{c}}$ interval), $\mathrm{g}$ mottled grey and red-brown condensed bed sequence of packstone separated by hardgrounds and unconformities $\left(\mathrm{O}_{\mathrm{b}}\right.$ interval), $\mathbf{h}$ glauconitic packstone-grainstone with thin elongate bivalve shells, trilobite and echinoderm fragments, and scattered orthoceratites $\left(\mathrm{O}_{\mathrm{a}}\right.$ interval), $\mathbf{i}$ brown bioturbated mudstone with dissolution surfaces (hardgrounds) often enriched with dark green glauconite $\left(\mathrm{O}_{\mathrm{a}}\right.$ interval $)$

\section{$O_{d}$ interval}

The clearest change of the wire-line log-motifs occurs over the $\mathrm{O}_{\mathrm{d}}$ interval. The up to 20-m-thick interval begins with a high GR peak representing the Kinnekulle Bentonite followed by a series of beds displaying highly variable logmotifs. The $\mathrm{O}_{\mathrm{d}}$ interval is easily traced in all investigated wells, especially in the ones on Gotland (Fig. 5). The rock types occurring in the Hamra-10 core are varied in composition and colour (Fig. $6 \mathrm{c}-\mathrm{d}$ ). The $\mathrm{O}_{\mathrm{d}}$ interval in the Grötlingbo-1 core (415.4-425.4 m), was assessed by Männik et al. (2015) to include the Skagen Limestone, Gräsgård Siltstone, Slandrom Limestone and Fjäcka Shale. A similar division of the Grötlingbo-1 core was made by Kjellström (1971) with slightly different depths, which was mainly due to different sampled levels. Kjellström also used the older classification of Macrourus Limestone for an interval that is now defined as the Gräsgård Siltstone by Männik et al. (2015). Dense grey and light brown grainstone and wackestone with irregular anastomosing sutured microstylolites, dark grey and brown discontinuity surfaces and clay laminae compose much of the lower part of the $\mathrm{O}_{d}$ interval in the Hamra-10 core, which can reach thicknesses of up to $5 \mathrm{~m}$ in some wells. This is followed by an interval marked by several irregular dark brown, pyritic and highly irregular discontinuity surfaces associated with beige grainstone/ packstone with winding laminae tentatively interpreted as biogenic encrustation of algae (Fig. 6d). The bedding over this interval is in the Hamra-10 core strongly discontinuous and disrupted. Similar features have been described in the Slandrom Limestone interval in southern Sweden, and the Saunja Formation in Estonia and Latvia, which have been taken as evidence for a widespread regression and subaerial exposure in the middle Katian (Calner et al. 2010). Significant stratigraphic gaps in the basal $\mathrm{O}_{\mathrm{d}}$ interval in the
Grötlingbo-1 core are also pointed out by Kjellström (1971) and Männik et al. (2015).

The upper part of the $\mathrm{O}_{\mathrm{d}}$ interval is composed of dark brown and greenish brown calcareous mudstone characterized in the wire-line logs by very high GR values. The FDC and the CNL logs indicate somewhat less dense and clayrich beds over this interval which is interpreted to represent the Fjäcka Shale (Fig. 6c). In the Grötlingbo-1 core, a similar succession of mudstones between 415.4 and $420.3 \mathrm{~m}$ has been defined as the Fjäcka Shale by Männik et al. (2015). The thickness is most commonly around five meters in the studied wells which fits to thicknesses noted in localities on the Swedish mainland (Ebbestad and Högström 2007). However, in our study area, the lithology is dominated by mudstone in contrast to the otherwise mainly organic-rich Fjäcka Shale observed in wells on the Swedish mainland.

The transition between the Skagen Limestone and Fjäcka Shale in the upper part of the $\mathrm{O}_{\mathrm{d}}$ interval is found to have a consistent distribution and geophysical characteristics in the studied area (Fig. 5). This correlates to a period of sub-aerial exposure resulting in karstification of the Slandrom Limestone, followed by flooding and the subsequent deposition of the Fjäcka Shale. This is consistent with observations by Tuuling and Flodén (2000) and Calner et al. (2010) who also interpret such changes in depositional environment to have been widespread.

\section{$\mathbf{O}_{\mathrm{e}}$ interval}

This interval has a highly variable thickness related to the local occurrence of carbonate mud mounds. This interval can, locally, reach thicknesses of $50 \mathrm{~m}$ in wells located in the northeast part of the study area, e.g., Skäggs-1, BO-21 and BO-12. However, it is considerably thinner in the wells to the south, e.g., B-7, B-3 and BO-11 (Fig. 5). This coincides with a mound belt extending from northeast Gotland towards Estonia (Kröger et al. 2017). The diameter of the mounds reaches up to $2 \mathrm{~km}$ where the greatest mounds are found offshore Gotland to the northeast (Tuuling and Flodén 2000). Characterization of ca 150 mounds on Gotland in the OPAB seismic data set gives a mean diameter of $640 \mathrm{~m}$ and a mean thickness of $19 \mathrm{~m}$ (Levendal et al. 2019). The rock types coupled to the mounds have been subdivided into (1) intra-mound facies characterized by irregularly bedded, light grey and beige, vuggy algal limestone with fenestral fabric and stromatactis, (2) mound cap and flank facies dominated by mottled (bioturbated) dark grey packstone, and (3) supra-mound facies with dark greyish green, subhorizontally bedded wackestones and calcareous mudstone with irregular lamina of clay (Sivhed et al. 2004). Figure 6b illustrates an example of the intra-mound fenestral bindstone with oil impregnated microfractures and vugs. A typical 
supra-mound calcareous mudstone/wackestones with undulating clay laminae is shown in Fig. 6a.

Bergström et al. (2004) showed that the main phase of mound development occurred on Gotland during the Pirgu stage, i.e., Klasen mounds located within the Jonstorp Formation. Beside this, a mound in the Liste-1 well on Gotland was defined as representing an earlier stage of mound development in the Rakvere-Nabala stages (Liste mounds), which would then accordingly be within the $\mathrm{O}_{\mathrm{d}}$ interval and the Slandrom Limestone (Bergström et al. 2004; Kröger et al. 2017).

\section{The Ordovician-Silurian boundary strata}

The stratigraphic division of the succession belonging to the Hajala-Porkuni stages is relatively well defined owing to the detailed biostratigraphic work by Männik et al. (2015) which complements the work by Kjellström (1971). Their results verify that the Silurian-Ordovician boundary is slightly deeper than the main lithological shift from marlstone to limestone (at $387 \mathrm{~m}$ in the Grötlingbo-1 well), which has been interpreted as the boundary according to OPAB. Instead, in the Grötlingbo-1 well, Männik et al. (2015) and Kjellström (1971) quote depths of 397.1 and $400 \mathrm{~m}$ for the Silurian-Ordovician boundary, respectively. The Silurian-Ordovician boundary often appears to coincide with a somewhat less pronounced lithological change between the limestone in the Ordovician and the argillaceous limestone in the Silurian. Similar gradual or less distinct transitions in lithology below the transition from marl to limestone can be observed in most wells on southern Gotland and are interpreted here as the top of the Ordovician (Fig. 5). Hence, the top Ordovician appears to be generally slightly deeper than noted in the OPAB well reports. It is striking, however, that the boundary is locally very distinct in wells to the northeast and offshore to the east of Gotland (Fig. 5). In these wells, there is a marked drop in the GR log and increase in density over the boundary, which is coupled to marlstone/claystone directly overlying pure and dense limestone. Tuuling and Flodén (2000) identified erosional unconformities in seismic data associated to the boundary to the northeast of Gotland. They interpreted this to reflect the global sea-level drop during Hirnantian glaciation leading to exposure and erosion of the shallow shelf. On south Gotland and offshore wells south of Gotland, representing slightly deeper Ordovician depositional settings, the boundary interval is characterized by a more gradual shift in lithology without any similar erosional unconformity. The overlying Silurian is composed of Llandovery shale followed by marlstone and claystone which is seen as a shift to higher GR values and less dense rock types. A Lower Visby Formation affinity is uncertain since the subsurface Silurian stratigraphy on Gotland still needs to be properly defined.

\section{Seismic signature}

When considering the physical properties of the Palaeozoic sequence within the study area, some of the largest contrasts can be found in and around the Ordovician interval. For example, there is typically a large contrast between the density and seismic velocity of the limestones of the Ordovician interval and the Cambrian and Silurian strata. Furthermore, there is a strong contrast in physical properties between the relatively argillaceous $\mathrm{O}_{\mathrm{d}}$ interval and the limestone of the $\mathrm{O}_{e}$ and $\mathrm{O}_{c}$ intervals. These significant and often sharp contrasts in physical properties generate strong seismic reflections. Over the years, several seismic studies have provided valuable insight into the Ordovician stratigraphy and a framework for the key seismic markers in the sequence has been established (Tuuling and Flodén 2009).

To date, most of seismic studies addressing the Ordovician interval within the Baltic Basin utilize high-resolution single-channel marine seismic data (100-200 Hz) (Flodén 1980; Tuuling et al. 1997; Tuuling and Flodén 2000, 2009). These data were collected primarily between 1966 and 1992 by Stockholm University and as part of a Swedish-Estonian collaboration project. Analysis of these data has allowed regional mapping and correlation of the sequence between Sweden and Estonia (Flodén 1980; Tuuling and Flodén 2009). The data also permitted a characterization of the size and distribution of the carbonate mounds offshore and to map regional erosional surfaces, within the $\mathrm{O}_{\mathrm{d}}$ interval and at the top of the $\mathrm{O}_{\mathrm{e}}$ interval (Tuuling and Flodén 2000). As part of these studies, four seismic markers were identified and mapped regionally within the Swedish part of the Baltic Sea. These includes the $\mathrm{O}_{1}$ marker corresponding to the base of the $\mathrm{O}_{\mathrm{a}}$ interval, the $\mathrm{O}_{3}$ marker corresponding to the base of the Rakvere Stage (within the $\mathrm{O}_{\mathrm{d}}$ interval), the $\mathrm{O}_{4-5}$ marker corresponding to the pair of reflections from the top and base of the Fjäcka Shale (within the $\mathrm{O}_{\mathrm{d}}$ interval), and the $S_{1}$ marker corresponding to the erosional boundary between the Ordovician and Silurian (Fig. 7, Tuuling and Flodén 2009). Tuuling and Flodén (2000) also mapped and described several seismic markers associated with the top of the Ordovician carbonate mounds and the top of the intermound sediments between Estonia and Sweden. However, it was not possible to correlate these reflections regionally.

Figure 7 exemplifies how the seismic markers described by Tuuling and Flodén (2009) relate to the well log intervals defined in this study. A series of synthetic seismograms are also shown which provide an estimate of how the Ordovician sequence in the Grötlingbo- 2 well would appear in the various seismic datasets used to investigate the Baltic Basin. The highest frequency synthetic seismogram $(150 \mathrm{~Hz})$ is representative of the data used by Tuuling and Flodén (2009), the central synthetic seismograms are representative of the OPAB land seismic data from the island of Gotland 
$(60-100 \mathrm{~Hz})$, while the lowest frequency synthetic $(30 \mathrm{~Hz})$ is representative of the marine seismic data from the OPAB dataset (e.g., Fig. 2). It is clear from Fig. 7 that strong positive reflection and negative reflection are typically associated with the top and the base of the Ordovician, respectively, in all the datasets. However, the seismic reflections associated with the $\mathrm{O}_{\mathrm{d}}$ interval $\left(\mathrm{O}_{4-5}\right.$ and $\left.\mathrm{O}_{3}\right)$ are only well resolved in the higher frequency land data from Gotland and the marine data of Tuuling and Flodén (2000, 2009). The synthetic seismograms also highlight the fact that the seismic reflections do not always align perfectly with the stratigraphic boundaries identified in this study. For example, the $S_{1}$ reflection occurs at the transition from marl to limestone, which lies above the top Ordovician boundary proposed in this study. Similarly, in this example, the $\mathrm{O}_{1}$ reflection is located a bit below the base of the $\mathrm{O}_{\mathrm{a}}$ interval.

Figure 8 shows an example profile through the Hemse-1 well on the central southern part of Gotland from a seismic dataset with relatively high-frequency content $(100 \mathrm{~Hz})$ from the OPAB dataset. Here reflections associated with the top

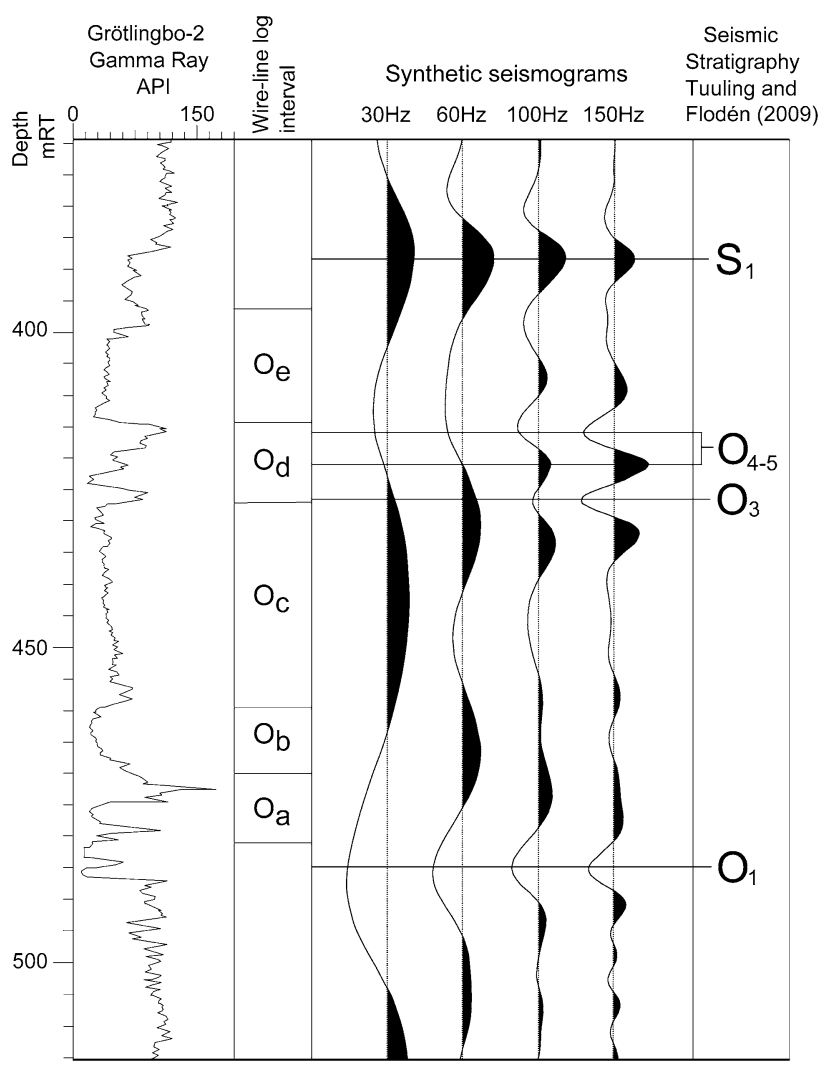

Fig. 7 Comparison of the well log intervals proposed in this study with the seismic markers of Tuuling and Flodén (2009) for the Grötlingbo-2 well. Synthetic seismograms are shown for a range of different frequencies to illustrate the resolution of different seismic datasets from the study area, where $30 \mathrm{~Hz}$ corresponds to the marine OPAB data, 60 and $100 \mathrm{~Hz}$ correspond to the onshore OPAB data and $150 \mathrm{~Hz}$ corresponds to the data of Tuuling and Flodén (2009) and base of the Ordovician and the $\mathrm{O}_{\mathrm{d}}$ interval can clearly be correlated across the section. As part of on-going efforts to digitize and interpret the OPAB seismic reflection data from Gotland (Sopher 2017; Levendal et al. 2019), it is clear some systematic differences in the seismic response exist across the island. For example, the reflection from the base of the Ordovician is typically more pronounced in the northwest parts of Gotland where the Faludden Sandstone is thin or missing. In these areas, there is a greater contrast in p-wave velocity between the Ordovician limestones and the siltstone and claystone of the Mossberga Member and hence, a stronger reflection is observed. Furthermore, the top Ordovician reflector is typically less pronounced towards the north, where the transition between the Ordovician and Silurian is more gradational than in the south, exemplified by Skäggs-1 and Skåls-1, respectively (Fig. 5). Beside the top and the base Ordovician reflectors, $\mathrm{O}_{4-5}$ and $\mathrm{O}_{3}$ can be observed on most of the higher frequency seismic profiles (Fig. 8). Reflections associated with the Upper Ordovician mounds are also part of the Ordovician seismic signature on Gotland. These commonly consist of weak and discontinuous reflections in dome-like structures often yielding a corresponding anticlinal feature in the top Ordovician reflector (Sivhed et al. 2004; Levendal et al. 2019).

\section{Discussion}

The evaluation of geophysical log-motifs for the Ordovician on Gotland and adjacent offshore areas shows that the succession can be subdivided into several unique intervals. The intervals can be traced on Gotland and in the adjacent offshore areas to the west and south of Gotland. Variably glauconitic carbonates and mudstones tentatively stratigraphically comparable to the Djupvik, Bjørkåsholmen and Köpingsklint formations are found in all the studied wells. The interval is in most wells characterized by two significant GR peaks defining two levels rich in glauconite. In occasional wells thin beds of alum shale also contribute to the lowermost peak making it difficult to define the boundary between alum shale and the glauconitic limestone. It is evident that the interval represents the major sea level drop occurring in the Pakerort to mid-Billingen Stages, which led to extremely starved sedimentation and the deposition of condensed sequences (cf. Fig. 3, Egenhoff et al. 2010). The glauconitic carbonates are followed by a stacked sequence of successively cleaner carbonates shown by a gradually falling GR response, indicating decreasing amount of clay minerals. These beds are predominantly composed of red and grey orthoceratite limestone corresponding to the Bruddesta to Persnäs limestones on Öland and the Dalby Limestone in Östergötland.

Our proposed Lower and Middle Ordovician stratigraphy of the Grötlingbo-1 core differs somewhat from 


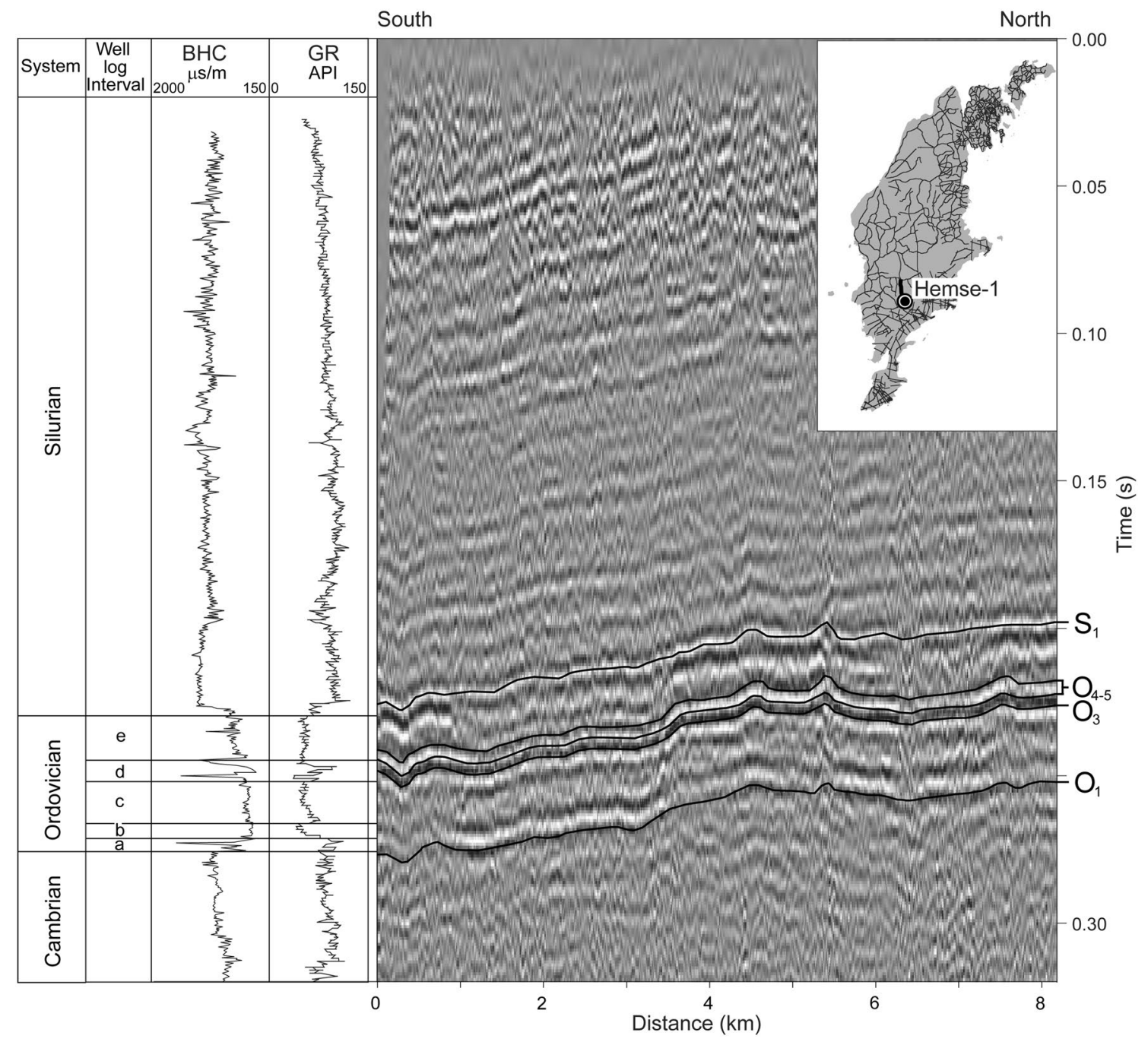

Fig. 8 Interpreted section crossing the Hemse-1 well on south central Gotland. The section exemplifies the typical seismic response of the Ordovician succession and its bounding strata in the onshore OPAB data. The associated geophysical log-motifs of the Natural gamma (GR) and borehole compensated sonic log (BHC) for the Hemse-1 well are shown the one by Kjellström (1971). His proposed division is merely based on two biozones and the fact that his data include barren intervals in the Oeland series. This opens the opportunity for alternative interpretations for this interval. Although, our interpretation is lacking conclusive biostratigraphical data it fits well with the general lithological characteristics and wire-line log-motifs and the results presented in Harris et al. (2007), Kiipli et al. (2008), Stouge (2004) and Calner et al. (2014). Furthermore, the results show that the thickness of the $\mathrm{O}_{b}-\mathrm{O}_{c}$ interval, interpreted to correspond to the Volkov-Haljala stages (Fig. 9) increases to the south. This thickening is most apparent in the $\mathrm{O}_{\mathrm{b}}$ interval (Fig. 5). This is interpreted to be related to the progressive and transgressive nature of the sea on the margin of the Baltoscandia during this time. It is also consistent with the interpretation that southern parts of the study area represent deeper shelf settings, within the Central Baltoscandian confacies belt and the northern parts represent shallower parts of the shelf in the North Estonian Confacies belt (cf. Fig. 1). OPAB named this interval the Bentonitic limestone, however, besides the Kinnekulle Bentonite the amount of bentonite layers is subordinate and not a defining character of the interval. For example, several thin bentonite layers are identified in the Grötlingbo-1 core (Snäll 1977) but these do not stand out in the geophysical log response. Thus, there is a need to further investigate the $\mathrm{O}_{b}$ and $\mathrm{O}_{c}$ intervals regarding stratigraphical affinity and propose a more adequate definition related to the Ordovician successions in adjacent area, for example Öland.

The most conspicuous log-motif occurs over the $\mathrm{O}_{\mathrm{d}}$ interval, interpreted here as the Slandrom Limestone and 


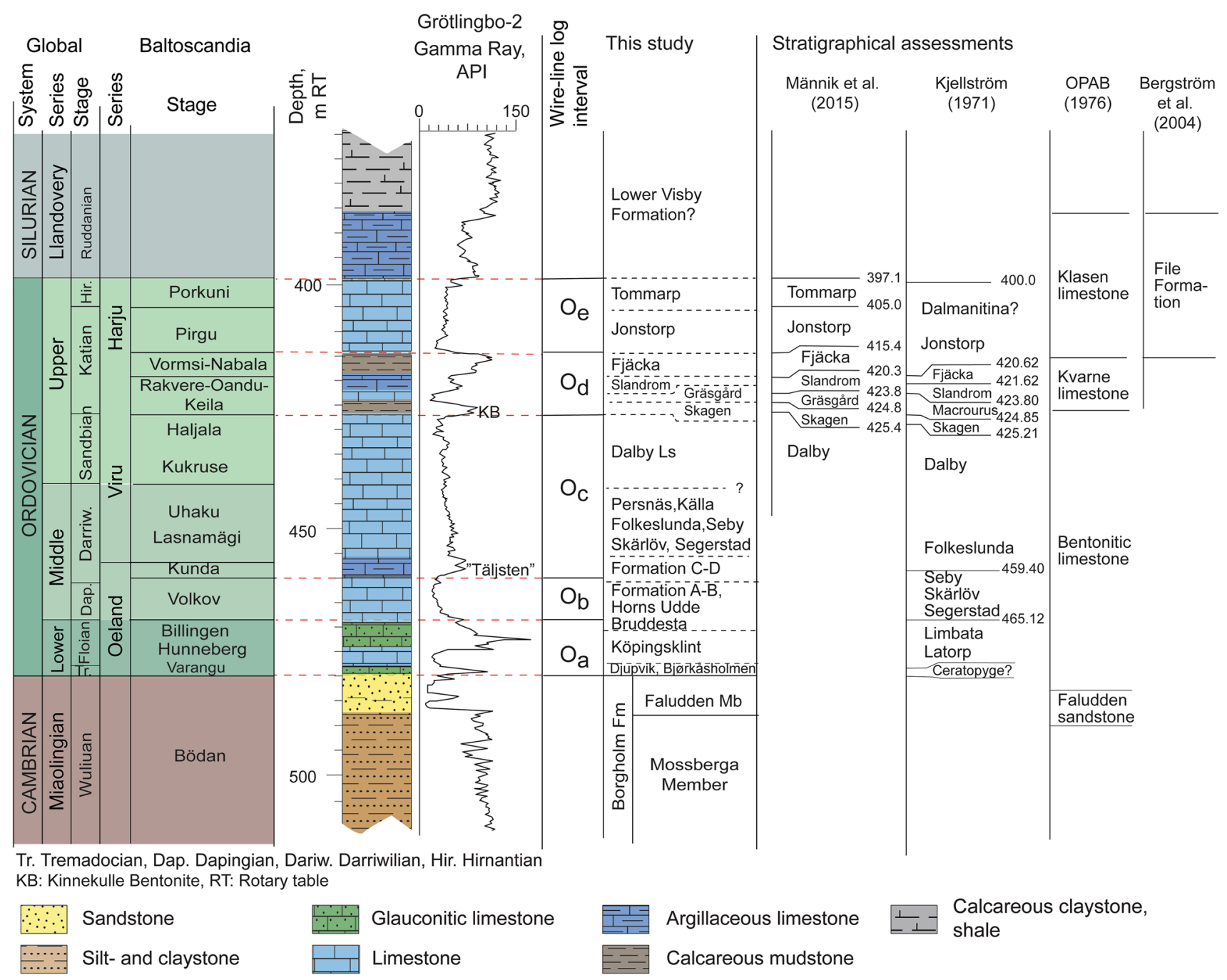

Fig. 9 Interpreted stratigraphic correlation of the identified wire-line $\log$ intervals $\left(\mathrm{O}_{\mathrm{a}}-\mathrm{O}_{\mathrm{e}}\right)$ in relation to the stratigraphic assessments by Kjellström (1971), OPAB (1976), Lundegårdh et al. (1985), Bergström et al. (2004) and Männik et al. (2015)

Fjäcka Shale interval (Fig. 9). The thickness of this interval is relatively consistent and the highly variable log-motif is interpreted to represent widespread sea-level drop and erosion. This led to the development of ravinement surfaces and karstification of the limestone followed by flooding and the formation of mudstones (Calner et al. 2010). The interval includes also an early phase of mud mound development, prior to the sea-level drop, i.e., Liste mounds (Bergström et al. 2004; Kröger et al. 2017). OPAB classified the lower limestone-dominated part of the $\mathrm{O}_{\mathrm{d}}$ interval as the Kvarne limestone. However, the upper and lower boundaries of the Kvarne limestone are not consistent in the OPAB reports. The division proposed here is easier to use as it fits with both existing stratigraphical data and geophysical responses and hence is more convenient for correlation purposes.

The great variation in thickness of the Katian-Hirnantian interval is largely related to the development of carbonate mud mounds, preferably in the northeast parts of Gotland. The log-motifs vary accordingly, where the intra mound rock types are dominated by relatively pure carbonates while the non-mound facies consists of more argillaceous carbonates, generating higher GR values. The thickness of this interval decreases significantly to the south as the number and size of the mounds decreases.

The study also shows that there is significant variation in the log-motifs across the Ordovician-Silurian boundary indicating quite different rock successions in the studied wells. In the offshore wells BO-21 and BO-12, there is a marked shift in the GR log from low to high values corresponding to an abrupt change from mound limestone to calcareous claystone. In other areas, the boundary strata are characterized by gradual changes as in Skäggs-1. Furthermore, in the B-3, B-7, BO-11, Hamra-10 and Skåls-1 wells, several meters of shale are observed on top of the Ordovician. In all, 
the variable log-motifs at this boundary indicate the heterogeneous effect of the Hirnantian sea level drop in the Baltic Basin. The effect of denudation on the Ordovician deposits when the sea retreated is interpreted to vary depending on the occurrence of denser mound limestone verses softer and more argillaceous rock types. According to the seismic data the mounds constitute often marked domelike structures in the top Ordovician marker. These have been assessed as residual dome structures which likely also locally affected the basal most Silurian depositional setting (Levendal et al. 2019). Beside this, there was also likely an effect related to how much the sea level dropped and how much of the area was exposed to erosion prior to the Silurian flooding. The shale identified on top of the Ordovician in the southerly wells is interpreted to represent an Early Silurian flooding event.

\section{Log-motifs and implications of $\mathrm{CO}_{2}$ seal integrity}

The sealing capacity of the Ordovician and Silurian successions constitute a key factor in evaluating the potential of $\mathrm{CO}_{2}$ storage in the Cambrian sandstone reservoirs in the Baltic Basin. This study shows an Ordovician succession of rock intervals with discrete lithological characteristic that can be related to the sealing properties of the rock itself. In general, the seal integrity of the Ordovician-Silurian is judged to be reliable since it has a total thickness of several hundred meters and consists, to a great extent, of impermeable argillaceous rock types. As a result, the anticipated risk of capillary leakage is low. A good sealing capacity is also inferred from the local occurrence of trapped hydrocarbons in the Miaolingian reservoir sandstone and Upper Ordovician carbonate mud mounds (Yang et al. 2016; Sivhed et al. 2004; Zdanaviciute and Lazauskiene 2004).

Conversely, the effect of chemical dissolution of the carbonate-dominated Ordovician succession in connection to storage of $\mathrm{CO}_{2}$ is a risk to consider. However, besides the limestone-dominated $\mathrm{O}_{\mathrm{b}}$ and $\mathrm{O}_{\mathrm{c}}$ intervals, the log-motifs in the studied wells show that the Ordovician succession includes argillaceous beds in the $\mathrm{O}_{\mathrm{a}}, \mathrm{O}_{\mathrm{d}}$ and $\mathrm{O}_{\mathrm{e}}$ intervals. The verified regional distribution, consistent log-motif and thickness of the Kinnekulle Bentonite, and the Fjäcka Shale are judged here to be significant barriers that would inhibit extensive dissolution of the Ordovician seal and subsequent leakage through the succession. Besides these intervals the mudstone beds in the $\mathrm{O}_{\mathrm{a}}$ interval as well as beds of alum shale contribute to the seal resistance to dissolution. This is especially the case in the south of Gotland where the alum shale has a more coherent distribution. Bildstein et al. (2010) also showed, by integrated geochemical modeling, that the impact of dissolution on a homogeneous carbonate caprock is less than a few meters over a period of 10,000 years. These results suggest that dissolution is not a considerable risk factor regarding the integrity of carbonate cap rocks. However, it is important to note that Bildstein et al. (2010) point out that heterogeneities in the rock mass, such as stylolites, vugs, bedding planes, fractures and faults can provide suitable conditions for creating significant dissolution pathways through a carbonate seal. Hence, information on these heterogeneities is essential in evaluating the seal integrity. We can see from the studied cores that micro-fractures, stylolites and irregular bedding planes are more frequent in the $\mathrm{O}_{b}, \mathrm{O}_{\mathrm{c}}$ and $\mathrm{O}_{\mathrm{e}}$ intervals (cf. Fig. 6b, e and f). It should also be noted that higher frequencies of micro-fractures and vugs, commonly oil stained, are found in connection to the carbonate mud mounds (Fig. 6b). The log-based division in this study could therefore be indirectly regarded as a framework for assessing which parts of the Ordovician seal are most sensitive to chemical dissolution. The possibility that fractures and faults could open up and create migration pathways if the pressure in the storage aquifer exceeds the formation integrity of the seal must also be considered. However, dissolution as well as hydraulically induced fracturing are considered to constitute low risks in comparison to leakage related to pre-existing fault zones, which can be found throughout the Baltic Basin (Šliaupienè and Šliaupa 2012). Even though the origin and migration history of the hydrocarbon accumulations within the basin is still not fully resolved, these faults are believed to have constituted the main migration pathways. The main source rock is proposed to be the Furongian-Tremadocian Alum Shale in the south parts of the Baltic Basin (Więcław et al. 2010; Kosakowski et al 2017; Yang et al. 2016). The Upper Ordovician Fjäcka Shale and Mossen Formation as well as the Llandovery shale have also been assessed as potential source rocks (Zdanaviciute and Lazauskiene 2004). The subsequent accumulations of oil is interpreted to have formed due to up dip migration, from the deepest parts of the basin, to the north and east during the Devonian (Wróbel et al. 2010). Fractures and faults are considered to be the most important migration pathways for the oil trapped in the Ordovician mounds during this time period (Yang et al. 2016). It is likely that some rearrangement of the trapped oil occurred during the Hercynian and Alpine tectonic regimes. Presently, it is unclear whether these interpreted fault-based migration pathways, which have been proposed for hydrocarbon migration, still constitute an integrity problem for the sub-mound Ordovician succession in the Swedish sector.

Finally, the log-motifs show that the basal part of the Silurian is characterized by very high GR values and an evident FDC and CNL offset indicating very argillaceous successions on top of the Ordovician. High GR values also indicate the presence of an extensive, up to $10 \mathrm{~m}$ thick shale unit in the southern part of the study area. This is judged to significantly contribute to the sealing capacity of the Ordovician to Lower Silurian succession. Based on these inferences it is possible to elaborate further investigations 
and evaluations of the sealing properties of the Ordovician succession.

\section{Conclusions}

The Ordovician succession displays relatively constant logmotifs in wells on Gotland and in the offshore area south and east of Gotland. The succession is divided into five geophysically unique intervals $\left(\mathrm{O}_{\mathrm{a}}-\mathrm{O}_{\mathrm{e}}\right)$. Comparison with core material from Hamra-10, Skåls-1 and Grötlingbo-1 have allowed the correlation of the log-motifs on Gotland to lithofacies and detailed stratigraphic analysis performed on similar strata on Öland, in Östergötland and Estonia. The results show for the first time the significance of the geophysical log data when comparing the Ordovician succession beneath Gotland and the offshore areas with defined stratigraphic successions in adjacent outcrop areas. This prepares the way for further evaluations of the depositional evolution of the Ordovician succession in the Baltic Basin. The improved understanding of the Ordovician sequence in this part of the Baltic Basin and the associated log-motifs also contributes to the knowledge concerning the cap rock suitability of the Ordovician for potential $\mathrm{CO}_{2}$ storage in the underlying Faludden Sandstone.

Open Access This article is distributed under the terms of the Creative Commons Attribution 4.0 International License (http://creativeco mmons.org/licenses/by/4.0/), which permits unrestricted use, distribution, and reproduction in any medium, provided you give appropriate credit to the original author(s) and the source, provide a link to the Creative Commons license, and indicate if changes were made.

\section{References}

Ahmed M, Lehnert O, Fuentes D, Meinhold G (2014) Origin of oil and bitumen in the Late Devonian Siljan impact structure, central Sweden. Org Geochem 68:13-26

Anthonsen KL, Aagaard P, Bergmo PES, Gislason SR, Lothe AE, Mortensen GM, Snæbjörnsdóttir SÓ (2014) Characterization and selection of the most prospective $\mathrm{CO}_{2}$ storage sites in the Nordic region. Energy Procedia 63:4884-4896

Bergström SM, Löfgren A, Grahn Y (2004) The stratigraphy of the Upper Ordovician carbonate mounds in the subsurface of Gotland. GFF 126:289-296

Bergström SM, Chen X, Gutierrez-Marco JC, Dronov A (2009) The new chronostratigraphic classification of the Ordovician System and its relations to major regional series and stages and to $\delta^{13} \mathrm{C}$ chemostratigraphy. Lethaia 42:97-107

Bergström SM, Calner M, Lehnert O, Noor A (2011) A new upper Middle Ordovician-lower Silurian drillcore standard succession from Borenshult in Östergötland, southern Sweden: 1: stratigraphical review with regional comparisons. GFF 133:149-171

Bildstein O, Kervévan C, Lagneau V, Delaplace P, Crédoz A, Audigane P, Per-fetti E, Jacquemet N, Jullien M (2010) Integrative modeling of caprock integrity in the context of $\mathrm{CO}_{2}$ storage: evolution of transport and geochemical properties and impact on performance and safety assessment. Oil Gas Sci Technol 65:485-502

Bjerkéus M (2001) The lower and middle Devonian of the southeastern Baltic Sea. GFF 123:97-105

Buchardt B, Nielsen AT, Schovsbo NH (1997) Alun skiferen i skandinavien. Geol Tidskrift 3:30

Calner M, Lehnert O, Nōlvak J (2010) Palaeokarst evidence for widespread regression and subaerial exposure in the middle Katian (Upper Ordovician) of Baltoscandia: significance for global climate. Palaeogeogr Palaeoclimatol Palaeoecol 296:235-247

Calner M, Lehnert O, Wu R, Dahlqvist P, Joachimski J (2014) $\delta^{13} \mathrm{C}$ chemostratigraphy in the lower-middle Ordovician succession of Öland (Sweden) and the global significance of the MIDICE. GFF 136:48-54

Calner M, Ahlberg P, Lehnert O, Erlström M (2013) The lower Palaeozoic of southern Sweden and the Oslo Region, Norway. In: Filed Guide for the 3rd Annual Meeting of the IGCP project 591. Sveriges geologiska undersökning, Rapporter och Meddelanden, vol 133, p 96

Cocks LRM, Torsvik TH (2006) European geography in a global context from the Vendian to the end of the Palaeozoic. In: Gee DG, Stephenson RA (eds) European lithosphere dynamics, pp 83-95. Geological Society, London

Cocks LRM, Torsvik TH (2005) Baltica from the late Precambrian to mid-Palaeozoic times: the gain and loss of a terrane's identity. Earth Sci Rev 72:39-66

Dahlqvist P, Bastani M, Persson L, Triumf CA, Erlström M, Gustafsson M, Jørgensen F, Gulbrandsen M, Malmberg-Persson K (2018) SkyTEM-undersökningar på Öland-Geologiska tolkningar och hydrogeologisk tillämpning. Sveriges geologiska undersökning. Rapporter Meddelanden 145:73

Dronov AV, Ainsaar L, Kaljo D, Meidla T, Saadre T, Einasto R (2011) Ordovician of Baltoscandia: facies, sequences and sea level changes. In: JC Gutierrez-Marco, I Rábano and D Garci'aBellido (eds.): Ordovician of the World, pp 143-150. Cuadernos del Museo Geominero, Instituto Geológico y Minero de Espan, Madrid

Dronov A, Rozhnov S (2007) Climatic changes in the Baltoscandian basin during the Ordovician: sedimentological and paleontological aspects. Acta Palaeontol Sin 46:108-113

Dronov A (2017) Ordovician sequence stratigraphy of the Siberian and Russian platforms. In: Montenari M (ed) Stratigraphy and timescales. Adv Seq Stratigr 2:187-241.

Dunham RJ (1962) Classification of carbonate rocks according to depositional texture. In: Ham WE (ed) Classification of carbonate rocks. American Association of Petroleum Geologists Memoir, pp 108-121.

Ebbestad JOR, Högström AES (2007) Ordovician of the Siljan district, Sweden. In: Ebbestad JOR, Wickström LM, Högström AES (eds), WOGOGOB 2007. 9th Meeting of the Working Group on Ordovician Geology of Baltoscandia. Field Guide and Abstracts. Sveriges Geologiska Undersökning Rapporter och meddelanden, vol 128, pp 7-26.

Egenhoff S, Cassle C, Maletz J, Frisk ÅM, Ebbestad JOR, Stübner K (2010) Sedimentology and sequence stratigraphy of a pronounced Early Ordovician sea level fall on Baltica-the Bjørkåsholmen Formation in Norway and Sweden. Sedimentary Geol 234:1-14

Flodén T (1980) Seismic stratigraphy and bedrock geology of the central Baltic. Stockholm Contrib Geol 35:240

Flügel E (2004) Microfacies of carbonate rocks. Analysis, interpretation and application. Springer, Berlin, Heidelberg, p 976

Harris PM, Saller AH, Simo JAT (1999) Advances in carbonate sequence stratigraphy: applications to reservoirs, outcrops and models. Society of Sedimentary Geology, Special publication $63: 421$ 
Harris MT, Ainsaar L, Dronov A (2007) The impact of Ordovician Climate Change on the Carbonate Facies of the East Baltic (Estonia and northwest Russia. In: Ebbestad JO, Wickström L (eds) WOGOGOB 2007. 9th meeting of the Working Group on the Ordovician Geology of Baltiscandia. Field guide and Abstracts. 91-92. Sveriges geologiska undersökning, Rapporter och Meddelanden, vol 128, pp 114

Hedström H (1923) Remarks on some fossils from the diamond boring at the Visby Cement factory. Sveriges Geol Undersökning C $314: 27$

Hood SH, Nelson CS, Kamp PJJ (2003) Lithostratigraphy and depositional episodes of the Oligocene carbonate-rich Tikorangi Formation, Taranaki Basin, New Zealand. N Z J Geol Geophys 46:363-386

Jaanusson V (1973) Aspects of carbonate sedimentation in the Ordovician of Baltoscandia. Lethaia 6:11-34

Jaanusson V (1976) Faunal dynamics in the Middle Ordovician (Viruan) of Baltoscandia. In: Basset MG (ed) The Ordovician system: proceedings of a paleontological association symposium, Birmingham,1974. Cardiff, pp 301-326

Japsen P, Green PF, Bonow JM, Erlström M (2015) Episodic burial and exhumation of the southern Baltic Shield: Epeirogenic uplifts during and after breakup of Pangea. Gondwana Res 35:357-377

Kiipli E, Kallaste T, Kiipli T (2008) Hydrodynamic control of sedimentation in the Ordovician (Arenig-Caradoc) Baltic Basin. Lethaia 42:127-137

Kjellström G (1971) Ordovician microplancton (Baltisphaerids) from Grötlingbo borehole no. 1 in Gotland, Sweden. Sveriges Geol Undersökning C 655:75

Kosakowski P, Kotarba MJ, Piestrzyński A, Shogenova A, Więcław D (2017) Petroleum source rock evaluation of the Alum and Dictyonema Shales (Upper Cambrian-Lower Ordovician) in the Baltic Basin and Podlasie Depression (eastern Poland). Int J Earth Sci 106:743-761

Kröger B, Hints L, Lehnert O (2017) Ordovician reef and mound evolution: the Baltoscandian picture. Geol Mag 154:683-706

Levendal T, Lehnert O, Sopher D, Juhlin C, Erlström M (2019) Ordovician carbonate mud mounds of the Baltoscandian Basin in time and space - a geophysical approach. Palaeogeogr Palaeoclimatol Palaeoecol (under review)

Lidmar-Bergström K, Olvmo M (2015) Plains, steps, hilly relief and valleys in northern Sweden-review, interpretations and implications for conclusions on Phanerozoic tectonics. Geol Survey Sweden Res Papers C 838:42

Lindskog A (2017) Early-Middle Ordovician biotic and sedimentary dynamics in the Baltoscandian paleobasin. Litholund Theses $29: 132$

Lundegård PH, Wikström A, Bruun Å (1985) Beskrivning till översiktliga berggrundskartan Oskarshamn. Sveriges Geol undersökning B 34:26

Männik P, Loydell DK, Nestor V, Nõlvak J (2015) Integrated Upper Ordovician-lower Silurian biostratigraphy of the Grötlingbo-1 core section, Sweden. GFF 137:225-234

Milton NJ, Emery D (1996) Outcrop and well data. In: Emery D, Myers KJ (eds) Sequence stratigraphy. 61-79. BP Exploration, Stockley Park, Uxbridge, London

Mortensen GM, Bergmo PES, Emmel BU (2016) Characterization and estimation of $\mathrm{CO}_{2}$ storage capacity for the most prospective aquifers in Sweden. Energy Procedia 86:352-360

Munnecke A, Calner M, Harper DAT, Servias T (2010) Ordovician and Silurian sea-water chemistry, sea level, and climate: a synopsis. Palaeogeogr Palaeoclimatol Palaeoecol 296:389-413

Nestor H, Soesoo A, Linna A, Hints O, Nòlvak J (2007) The Ordovician of Estonia and southern Finland. Institute of Geology at Tallinn University of Technology and University of Turku,
Department of Geology. MTÜ GEOGuide Baltoscandia. Tallinn, p 32 (ISBN 978-9985-9867-1-4)

Nielsen AT (2004) Ordovician sea level changes: a Baltoscandian perspective. In: Webby BD, Paris F, Droser M, Percival I (eds) The great Ordovician diversification event. Colombia University Press, New York, pp 84-93

OPAB (1976) Gotland-exploration activities 1972-76. Geology and petroleum prospects, Geological Survey of Sweden Archive, p 75

Rider MH, Kennedy M (2011) The Geological Interpretation of Well logs, 3rd Revised edition. Rider-French Consulting Ltd., p 440

Schlumberger (1991) Log interpretation principles/applications. Schlumberger Well Services, Houston

Serra O (1984) Fundamentals of Well log interpretation. Volume 2: The interpretation of logging data. Elsevier, Cham, p 684

Shogenov K (2008) Correlation of the Ordovician bedrock in the South Estonian boreholes by petrophysical and geochemical properties. Master thesis AKG34LT, Tallinn, $62 \mathrm{pp}$ and attachments $20 \mathrm{pp}$.

Sivhed U, Erlström M, Bojesen-Koefoed JA, Löfgren A (2004) Upper Ordovician carbonate mounds on Gotland, central Baltic Sea: distribution, composition and reservoir characteristics. J Petrol Geol 27:115-140

Šliaupiene R, Šliaupa S (2012) Risk factors of $\mathrm{CO}_{2}$ geological storage in the baltic sedimentary basins. Geologija 54:100-123

SnäIl S (1977) Silurian and Ordovician bentonites of Gotland (Sweden). Stockholm Contrib Geol 31:1-80

Sopher D (2017) Converting scanned images of seismic reflection data into SEG-Y format. Earth Sci Inf 11:241-255

Sopher D, Juhlin C (2013) Processing and Interpretation of vintage 2D marine seismic data from the outer Hanö Bay Area, Baltic Sea. J Appl Geophys 95:1-15

Sopher D, Juhlin C, Erlström M (2014) A probabilistic assessment of the effective $\mathrm{CO}_{2}$ storage capacity within the Swedish sector of the Baltic Basin. Int J Greenhouse Gas Control 30:148-170

Sopher D, Erlström M, Bell N, Juhlin C (2016) The structure and stratigraphy of the sedimentary succession in the Swedish sector of the Baltic Basin: New insights from vintage 2D marine seismic data. Tectonophysics 676:90-111

Stephansson O (1971) Gravity tectonics on Öland. Bull Geol Inst Univ Upsala New Ser 3:37-78

Stouge S (2004) Ordovician siliciclastics and carbonates of Öland, Sweden. Erlanger Geol Abhandlungen Sonderband 5:91-111

Thorslund P (1968) The Ordovician-Silurian boundary beneath Gotland. Geologiska Föreningens I Stockholm Förhandlingar 90:443-451

Thorslund P, Westergård AH (1938) Deep boring through the CambroSilurian at File Haidar, Gotland. Preliminary report. Sveriges Geol Undersökning C 415:48

Tuuling I, Flodén T (2000) Late Ordovician carbonate buildups and erosional features northeast of Gotland, northern Baltic Sea. GFF 122:237-249

Tuuling I, Flodén T (2009) Seismic correlation of Palaeozoic rocks across the northern Baltic Proper-Swedish-Estonian project since 1990, a review. Estonian J Earth Sci 58:273-285

Tuuling I, Flodén T (2016) The Baltic Klint beneath the central Baltic Sea and its comparison with the North Estonian Klint. Geomorphology 263:1-18

Tuuling I, Flodén T, Sjöberg J (1997) Seismic correlation of the Cambrian sequence between Gotland and Hiiumaa in the Baltic Sea. GFF 119:45-54

Vlierboom FW, Collini B, Zumberge JE (1986) The occurrence of petroleum in sedimentary rocks of the meteor impact crater at Lake Siljan. Sweden Org Geochem 10:153-161

Więcław D, Kotorba MJ, Lewan MD, Karczewska A (2010) Comparison of oils accumulated in the Polish Baltic Basin with hydrous pyrolysis oils expelled from Cambrian and Ordovician rocks. In: 
Proceedings from the International Conference "Baltic Petrol 2010”, pp 33-34

Wróbel M, Kosakowski P, Źurawski E (2010) Expulsion, migration and accumulation processes in the Lower Palaeozoic strata of Polish Baltic Basin (2-D modelling). In: Proceedings from the International Conference "Baltic Petrol 2010", pp 47-48

Yang S, Schultz HM, Hemmingsen Schovsbo N, Bojesen-Koefoed JA (2016) Oil-source-rock correlation of the Lower Paleozoic petroleum system in the Baltic Basin (northern Europe). AAPG Bull 101:1971-1993

Zdanaviciute O, Lazauskiene J (2004) Hydrocarbon migration and entrapment in the Baltic Syneclise. Org Geochem 35:517-527 